\title{
Anatexis at the roof of an oceanic magma chamber at IODP Site 1256 (equatorial Pacific): An experimental study
}

Martin Erdmann ${ }^{1,2, *}$, Lennart A. Fischer ${ }^{1}$, Lydéric France ${ }^{2}$, Chao Zhang ${ }^{1}$, Marguerite

Godard $^{3}$, and Jürgen Koepke ${ }^{1}$

${ }^{1}$ Institut für Mineralogie, Leibniz Universität Hannover, Callinstr. 3, 30167 Hannover, Germany

${ }^{2}$ CRPG; UMR 7358, CNRS; Université de Lorraine, 15 rue Notre Dame des Pauvres, 54501 Vandœuvre-lès-Nancy, France

${ }^{3}$ Géosciences, Université Montpellier 2, Place Eugène Bataillon, 34095 Montpellier, France

*corresponding author: m.erdmann@mineralogie.uni-hannover.de; phone: +49 511762 5074; fax: +495117623045

Keywords

Experimental petrology

Partial melting

Fast-spreading mid-ocean ridge

Oceanic plagiogranite

Granoblastic hornfels

Conductive boundary layer 


\section{ABSTRACT}

Replenished axial melt lenses at fast-spreading mid-oceanic ridges may move upward and intrude into the overlying hydrothermally-altered sheeted dikes, resulting in high-grade contact metamorphism with the potential to trigger anatexis in the roof rocks. Assumed products of this process are anatectic melts of felsic composition and granoblastic, twopyroxene hornfels, representing the residue after partial melting. Integrated Ocean Drilling Program expeditions 309, 312, and 335 at Site 1256 sampled such a fossilized oceanic magma chamber in the eastern equatorial Pacific. In this study, we simulated magma chamber roof rock anatectic processes by performing partial melting experiments using six different protoliths from the Site 1256 sheeted dike complex, spanning a lithological range from poorly- to strongly-altered basalts to partially- or fully-recrystallized granoblastic hornfels.

Results show that extensively altered starting material lacking primary magmatic minerals cannot reproduce the chemistry of natural felsic rocks recovered in ridge environments, especially elements sensitive to hydrothermal alteration (e.g., $\mathrm{K}, \mathrm{Cl}$ ). Natural geochemical trends are reproduced through partial melting of moderately-altered basalts from the lower sheeted dikes. Two-pyroxene hornfels, the assumed residue, were reproduced only at low melting degrees $(<20$ vol\%). The overall amphibole absence in the experiments confirms the natural observation that amphibole is not produced during peak metamorphism. Comparing experimental products with the natural equivalents reveals that water activity $\left(a \mathrm{H}_{2} \mathrm{O}\right)$ was significantly reduced during anatectic processes, mainly based on lower melt aluminum oxide and lower plagioclase anorthite content at lower $a \mathrm{H}_{2} \mathrm{O}$. High silica melt at the expected temperature $\left(1000-1050^{\circ} \mathrm{C}\right.$; peak thermal overprint of two-pyroxene hornfels) could only be reproduced in the experimental series performed at $a \mathrm{H}_{2} \mathrm{O}=0.1$. 


\section{INTRODUCTION}

Anatectic processes associated with the dynamic behavior of crystal mush zones with an overlying axial melt lens (AML) at fast-spreading mid-ocean ridges have major influences on the composition of the oceanic crust. Based on geophysical studies (e.g., Caress et al. 1992; Crawford et al. 1999; Lamoureux et al. 1999; Dunn et al. 2000) and field observations in ophiolites (e.g., Nicolas et al. 1988, 2000; Gillis and Coogan 2002; Umino et al. 2003; France et al. 2009), the crystal mush zone at fast-spreading mid-ocean ridges has a melt fraction of less than 20\% (e.g., Caress et al. 1992; Crawford et al. 1999; Lamoureux et al. 1999; Dunn et al. 2000), and is located between the Moho and the sheeted dikes. At the top of the crystal mush zone, directly beneath or within the sheeted dike root zone, a small ( $50-100 \mathrm{~m}$ thick and $\sim 1000$ m wide) melt lens is commonly present (e.g, Detrick et al. 1987). This AML, locally filled with nearly-pure basaltic melt (e.g., Detrick et al. 1987; Dunn et al. 2000), feeds the basalts of the upper crust and is assumed to be the place where the main stage of midocean ridge basalt (MORB) differentiation occurs. The AML roof is a very complex horizon, where magmatic processes interact with metamorphic overprint and hydrothermal influence (Coogan et al. 2003; Nicolas et al. 2008; France et al. 2009, 2013). Below this horizon the AML is filled with a basaltic magma at a temperature of $\sim 1200^{\circ} \mathrm{C}$, and above it the seawaterderived hydrothermal cells operate at temperatures $<600^{\circ} \mathrm{C}$ (Alt et al. 2010). The two convective systems are thought to be separated by a thin conductive boundary layer $(\sim 100 \mathrm{~m}$ thick; e.g., Lister 1974) that has a maximum thermal gradient of approximately $3^{\circ} \mathrm{C} / \mathrm{m}$ (Koepke et al. 2008), by far the most extreme quasi-steady-state thermal boundary on Earth. This boundary layer consists of granoblastic hornfels and former hydrothermally-altered sheeted dikes, which were contact-metamorphosed by the heat of the underlying dynamic AML. 
The combination of water influx due to the dehydration of the previously hydrothermally altered dikes and heat supply from an underlying AML (Detrick et al. 1987) may result in anatexis of magma chamber roofs (e.g., Gillis and Coogan 2002; Coogan et al. 2003; France et al. 2009, 2010, 2013, 2014). This is an important process at fast-spreading ridges, since the generated anatectic melts have the potential to skew the composition of fresh MORB (France et al. 2014). Evidence for MORB contamination by assimilation of altered lithologies at crustal levels is widespread at fast-spreading ridges (e.g., Perfit et al. 1983; Michael and Chase 1987; Michael and Cornell 1998; Coogan et al. 2003; Wanless et al. 2010, 2011; France et al. 2014).

Apart from MORB contamination, anatexis at the AML roof is recognized to be an important process that generates felsic melt in the sheeted dike root-zone of oceanic crust (e.g., Gillis and Coogan 2002; Koepke et al. 2004; Brophy 2009; France et al. 2010; Wanless et al. 2010; Grimes et al. 2013), where cross-cutting felsic dikes and veins are often observed (e.g., Wilson et al. 2006; France et al. 2009). The origins of these dikes and veins have been debated for decades (see below) yet are still poorly understood. Beard and Lofgren (1991) pointed out that if dehydration melting of hydrated basaltic rocks is a primary mechanism for the formation of silicic melts, large volumes of anhydrous, pyroxene- and plagioclase-rich restites would be predicted. It is verified that such rocks exist as granoblastic hornfels, sandwiched between the AML and the sheeted dikes, and they are well known both from modern oceanic crust (e.g., Wilson et al. 2006; Gillis 2008; Koepke et al. 2008; France et al. 2009, 2014) and from the Oman and Troodos ophiolites (e.g. Gillis and Coogan, 2002; Gillis, 2008; France et al., 2009).

The aim of the present study is to experimentally reproduce the complex anatectic processes occurring at the roof of fast-spreading oceanic ridge magma chambers by using six natural analogues recovered from Site 1256 of the Integrated Ocean Drilling Program (IODP) 
expeditions 309, 312, and 335 as starting materials. These materials span a lithological range from poorly- to strongly-altered dike basalt to partially- or fully-recrystallized granoblastic hornfels. The samples are well suited for characterizing the solidus temperatures for the different starting materials as well as for evaluating the compositional spectrum of the experimental melts and the residual minerals, and for addressing the question of whether water-saturated conditions are required for partial melting. Since the compositions of felsic veins as well as of the granoblastic hornfels from the drilled dike/gabbro transition at Site 1256 are available, a direct comparison of the experimental products with the corresponding natural counterparts is possible, enabling a very straightforward approach for unraveling the complex magmatic-metamorphic processes ongoing at the dike/gabbro transitions at fastspreading mid-oceanic ridges.

\section{BACKGROUND}

\section{Oceanic plagiogranites and granoblastic hornfels}

Oceanic crustal plagiogranites (see Koepke et al. 2007 for a review and definition) are typically found, although not in large volumes, in the upper oceanic crust. They have been described as vein networks and/or discrete intrusive bodies in ophiolites (Gillis and Coogan 2002; France et al. 2009, 2014) and as small felsic veins in the relatively young oceanic crust (e.g., Dick et al. 2000; Blackman et al. 2004; Teagle et al. 2006). The dike/gabbro transition of present day oceanic crust has been sampled at only three locations, all related to crust formed at the East Pacific Rise (EPR; IODP Site 1256, Pito Deep, and Hess Deep). Especially at Site 1256, oceanic plagiogranites have been typically recognized as small felsic veins (Wilson et al. 2006; Koepke et al. 2007), often in association with granoblastic hornfels. As the origin of $\mathrm{SiO}_{2}$-enriched rocks is still under controversial debate (extreme fractionation vs. partial melting vs. liquid immiscibility; e.g., Koepke et al. 2007), these rock associations are key to our understanding of felsic melt generation in oceanic crust. Focusing on partial 
melting, as this study does, the general survey of protoliths, products, and residues can shed light on this complex process.

Rocks from the conducting boundary layer were first described as pyroxene and/or hornblende hornfels (e.g., Gillis and Roberts 1999), which are very-fine-grained to microcrystalline granoblastic rocks corresponding to partially-to-completely re-crystallized, hydrothermally-altered dike rocks. The typical mineral assemblage of the pyroxene hornfels is clinopyroxene, orthopyroxene, magnetite, ilmenite, and plagioclase ( \pm amphibole). The presence of primary amphibole divides these rocks into "dry" and "wet" granoblastic subtypes. A detailed review of granoblastic hornfels evolution and characteristics for a present day oceanic crust is given by Koepke et al. (2008) and Alt et al. (2010).

Granoblastic hornfels were initially observed in ophiolites in intimate association with uppermost gabbros typically located within the dike/gabbro transition zone (Rothery 1983; Nicolas and Boudier 1991). Other studies from the Troodos and Oman ophiolites focused on processes occurring at the roof of a fossil AML and arrived at the general conclusion that the hornfels are the residues of a partial melting event above the AML, while the felsic veins correspond to the related anatectic melts (Gillis and Roberts 1999; Gillis and Coogan 2002; Gillis 2008; France et al. 2009). Granoblastic hornfels are also common in modern oceanic fast-spreading crust and can be directly linked to magma chamber roof processes, because they are sampled within the top of a frozen AML (Wilson et al. 2006; Gillis 2008; Koepke et al. 2008; Alt et al. 2010). Moreover, because the conductive boundary layer above an AML is mainly composed of granoblastic hornfels (Gillis 2008), these rocks are crucial for understanding the heat flux in the hydrothermally-influenced oceanic crust and the role of this altered crust as potential contaminator of fresh MORB melts.

\section{IODP Site 1256 stratigraphy}


IODP Site 1256, located in the eastern Pacific Ocean in $~ 15$ Ma old crust, is the only place on Earth where the dike-gabbro transition has been penetrated in a continuous drill section (Fig. 1; Wilson et al. 2006) and is, thus, perfectly suitable as a source of samples in this study. The gabbro sequence, interpreted as part of the frozen melt lens (Koepke et al. 2011), was reached within seismic layer 2 at $1407 \mathrm{~m}$ below seafloor (mbsf). This shallow level for the gabbros may be related to the high magmatic budget associated with the superfast EPR spreading rate (up to $220 \mathrm{~mm} /$ year; Wilson 1996) 19 to $12 \mathrm{Ma}$ ago. The extrusive part of the crust at Site 1256 is composed of a $\sim 100 \mathrm{~m}$ thick sequence of lava primarily comprised of a $>74 \mathrm{~m}$ thick ponded flow, followed by $\sim 700 \mathrm{~m}$ of sheet flows and massive lavas, and a relatively thin $(\sim 350 \mathrm{~m})$ sequence of sheeted dikes. The lower $\sim 60 \mathrm{~m}$ of the sheeted dikes are partially to completely re-crystallized to granoblastic hornfels, named "granoblastic dikes" by IODP Expedition 312 scientists (Teagle et al. 2006; Koepke et al. 2008; Alt et al. 2010). One hundred meters below the granoblastic hornfels two intrusive bodies of gabbro (52 $\mathrm{m}$ and 24 $\mathrm{m}$ thick) are present, separated by $24 \mathrm{~m}$ of granoblastic hornfels (Teagle et al. 2006; Koepke et al. 2011). The uppermost gabbros are strongly hydrothermally altered, indicating a deep influence of hydrothermal circulation. These gabbros, interpreted as part of an in-situ frozen AML (Koepke et al. 2011), bear xenoliths of granoblastic hornfels, considered as relics of former dikes, indicating that contamination of a melt lens by overlying roof rocks played a significant role in the evolution of the magmatic system (Teagle et al. 2006; France et al. 2009; Koepke et al. 2011).

\section{Previous experiments testing an anatectic origin of felsic melt in oceanic crust}

Numerous experiments on the dehydration melting of amphibolites and greenstones have been performed in the last decades, in order to investigate the formation of Archean TTG rocks (tonalites, trondhjemites, and granodiorites; Barker 1979; see summarizing chapter on “Dehydration Melting” in Johannes and Holtz 1996). Additionally, some partial melting 
experiments conducted under hydrous conditions using basaltic compositions as starting material showed that felsic melt production is possible by this process (Holloway and Burnham 1972; Helz 1973; Beard and Lofgren 1991; Kawamoto 1996). However, results of these studies are, for the most part, not directly applicable to the formation of felsic melt at the roof of a mid-ocean ridge AML, as most of the corresponding experiments were performed under elevated pressures $(\geq 300 \mathrm{MPa}$ ) in order to simulate typical dehydration melting processes related to subduction zones or deep continental basements. Such conditions are not relevant for anatectic processes occurring at the AML roof; these processes are characterized by low lithostatic pressures $(\leq 100 \mathrm{MPa})$ under potentially high water activity $\left(a \mathrm{H}_{2} \mathrm{O}\right)$ due to the low water solubility in silicate melts under such shallow pressures. Moreover, these studies used natural starting materials which are different from the lithologies present at the roof of oceanic magma chambers. One study that included experiments at low pressure (100 MPa) was performed by Beard and Lofgren (1991) who systematically investigated the effects of pressure and water on different metamorphosed protoliths. For simulating anatectic processes operating in the deep oceanic crust (e.g., Koepke et al. 2005a,b), partial melting experiments were performed using oceanic gabbro as starting material (Koepke et al. 2004; Wolff et al. 2013; Koepke et al. 2014). However, these studies used fresh, rather primitive cumulate gabbro as starting material, and did not address the special compositional nature of the AML roof rocks which consist of a rock spectrum ranging from hydrated, altered basalts to dry granoblastic hornfels.

The first experimental study using hydrothermally-altered basalt from the lower sheeted dikes as starting material was performed by France et al. (2010). The starting material for that study, however, was sampled in the Oman ophiolite, which may not be the best proxy for fast spreading ridges, because typical basalts from Oman are relatively enriched in $\mathrm{SiO}_{2}, \mathrm{Al}_{2} \mathrm{O}_{3}$, and $\mathrm{K}_{2} \mathrm{O}$ and depleted in $\mathrm{TiO}_{2}$ for a given $\mathrm{MgO}$ content as consequence of formation in a fore arc of a subduction zone (e.g. MacLeod et al. 2013). The starting material used in France et al. 
(2010) was thus relatively enriched in $\mathrm{SiO}_{2}, \mathrm{Al}_{2} \mathrm{O}_{3}$, and $\mathrm{K}_{2} \mathrm{O}$ (54.1, 16.2, and 0.2 wt\%, respectively, on an anhydrous basis); this rarely corresponds to the more primitive MORBs at Site 1256. Moreover, their starting material was fully altered (greenschist facies condition) and lacked any primary magmatic mineral, which is uncommon at Site 1256 , where the roof rocks are basalts bearing either primary phases or partially- to fully-recrystallized granoblastic hornfels. Thus, a direct application of France et al. (2010) experimental results to Hole 1256D should be performed with caution.

\section{EXPERIMENTAL AND ANALYTICAL TECHNIQUES}

\section{Starting material}

Six different samples from IODP Site 1256 were used as starting material for hydrous partial melting experiments, representative of the different basaltic lithologies of the drilled section. For petrographic details, modal amounts, and texture type classification indicating the grade of contact-metamorphic overprint according to Koepke et al. (2008) see Table A1 (electronic supplementary). The rocks were sampled at the lower part of the sheeted dike complex, close to the AML. Two of the samples are basalts showing different grades of typical hydrothermal alteration (D10: $27 \%$ alteration, D11: $11 \%$ ), containing low-grade hydrous alteration phases (e.g. actinolite, chlorite, secondary oxides) and preserved primary magmatic phases (plagioclase, clinopyroxene, oxides). Sample GD12 is a basalt with an initial granoblastic overprint (type 5 according to the classification of Koepke et al. 2008); GD12 is the sample with the highest grade of secondary low-grade alteration (43\%). Three samples show a strong imprint of contact-metamorphism expressed by granoblastic, hornfelsic textures composed of newly-formed plagioclase, clinopyroxene, orthopyroxene, and oxides. Sample GD14 shows a "wet", amphibole-rich paragenesis equilibrated in the amphibolite facies, while GF36 and GF38 are "dry" two-pyroxene hornfelses with amphibole only present as a secondary alteration phase in very small amounts (Table A1). Two of the six samples are significantly 
enriched in amphibole: GD12 has 36\% actinolitic amphibole as a result of hydrothermal alteration, while GD14 has 20\% hornblendic amphibole regarded as part of the prograde contact-metamorphism leading to the granoblastic overprint (see also microphotographs in Fig. 1).

Major and trace element data of the starting materials were determined by inductively coupled plasma optical emission spectroscopy (ICP-OES) and ICP-mass spectrometry (MS), respectively, at "ACTLABS" (Activation Laboratories Ltd., Ancaster, Ontario, Canada). While the major element compositions of the starting materials vary only slightly (e.g., $\mathrm{SiO}_{2}$ 48.6-51.5 wt\%; $\mathrm{Al}_{2} \mathrm{O}_{3}$ 12.1-15.0 wt\%; see Table 1), the trace element pattern of the whole rocks varies significantly from slightly enriched to more depleted compositions in comparison to typical N-MORB (see Fig. A1 in the electronic supplementary material). The starting materials with anhydrous granoblastic textures (two-pyroxene hornfels GF36 and GF45) are strongly depleted in light rare earth elements (LREEs) displaying marked $\mathrm{Sr}$ and Eu positive anomalies, and negative $\mathrm{Zr}$ and $\mathrm{Hf}$ anomalies as is typical of residues from a former partial melting event (France et al. 2014).

\section{Felsic rocks from IODP Site 1256}

A characteristic feature of the granoblastic hornfelses at IODP Site 1256 is that they contain intrusions of felsic, evolved plutonic rocks. These are small, irregular patches, veins $(\sim 1-2$ $\mathrm{mm}$ wide), and dikelets ( $<1.5 \mathrm{~cm}$ wide) consisting of oxide gabbro, diorite, tonalite, and trondhjemite (Wilson et al. 2006; Teagle et al. 2012) with a fine- to medium-grained granular texture. Here, for the comparison to experimental anatectic melts, we focus only on those felsic veins and dikelets of the Hole 1256D drill core characterized as tonalites based on the mineral mode. They are the most evolved samples of the sample suite and are minor secondary altered. Thus, they are best suited for a comparison with the experimental equivalents. The chemical bulk rock analyses of the tonalites show $\mathrm{SiO}_{2}$ contents varying 
between 62 and $70 \mathrm{wt} \%$ with contents of $\mathrm{MgO}$ varying between 1.1 and $2.1 \mathrm{wt} \%$ (Tab. 1). High amounts of $\mathrm{P}_{2} \mathrm{O}_{5}(0.19$ to $0.60 \mathrm{wt} \%)$ demonstrate the evolved character of the tonalites. N-MORB normalized rare earth element (REE) patterns of the tonalites are roughly flat with pronounced negative $\mathrm{Ba}, \mathrm{Rb}$, and $\mathrm{Sr}$ anomalies (Fig. A1). The positive $\mathrm{Zr}$ anomaly is strong and gradually enhanced by decreasing total REEs. Major and trace element compositions of the tonalitic veins from IODP Site 1256 also match those of typical oceanic plagiogranites from the Oman and Troodos ophiolites that form small-scale intrusions within the gabbrodike transition (Rollinson 2009; Gillis and Coogan 2002).

\section{Experiments}

For the experiments, the natural rocks were crushed and sieved. France et al. (2010) investigated the influence of starting material grain size on the composition of the experimental phases, and showed that the experimental products up to a grain size of $250 \mu \mathrm{m}$ exhibit identical phase compositions. Thus, a starting material grain size of 125 to $200 \mu \mathrm{m}$ was used here in order to obtain larger melt pools in low-temperature experiments, under virtually equilibrium conditions. Additionally, for low-temperature experiments close to the solidus we used "micro-rocks" as starting material (mm-sized fragments of the whole rocks; see Wolff et al. 2013) in order to obtain melt pools large enough for analysis. To ensure comparability among starting compositions, deionized water was added to the majority of the experiments in order to guarantee water-saturated conditions. Since all runs were performed at temperatures $\leq 1030^{\circ} \mathrm{C}$, Au capsules were used which afforded the advantage of avoiding $\mathrm{Fe}$ loss to the capsule material.

To simulate conditions prevailing directly above the AML, an $\mathrm{H}_{2}$-controlled internally-heated pressure vessel (IHPV) at the Institut für Mineralogie in Hannover, Germany was used. Temperature varied from $910^{\circ} \mathrm{C}$ to $1030^{\circ} \mathrm{C}$ in steps of $30^{\circ}$. The vessel was pressurized with argon gas to $100 \mathrm{MPa}$. This corresponds to a lithostatic pressure found at $\sim 2-3 \mathrm{~km}$ depth in 
oceanic crust. Even though this is slightly deeper than the environment where the samples used were obtained at the EPR, this pressure enables a direct comparison to other experimental studies (e.g., Beard and Lofgren 1991; France et al. 2010). Moreover, at lower pressure it is difficult to ensure stable conditions in the vessel, especially with regard to a defined oxygen fugacity $\left(f \mathrm{O}_{2}\right)$. The $f \mathrm{O}_{2}$ corresponds to QFM +1 (QFM corresponds to the $f \mathrm{O}_{2}$ of the quartz-fayalite-magnetite oxygen buffer) and was set with a defined $\mathrm{P}_{\mathrm{H} 2}$, depending on the experimental temperature, controlled by a Shaw membrane (e.g., Scaillet et al. 1992). While the $f \mathrm{O}_{2}$ for primitive, dry MORB melts is suggested to be slightly below (e.g. Bézos and Humler 2005) or slightly above QFM (Cottrell and Kelly 2011), the supposed hydrothermal influence in nature and the accompanying mostly water-saturated conditions in our experiments justify this higher $f \mathrm{O}_{2}$. A lower $f \mathrm{O}_{2}$ was simulated in one experimental series at $\mathrm{T}=1000^{\circ} \mathrm{C}$ where $\mathrm{CO}_{2}$ was added to the fluid phase in order to lower the $a \mathrm{H}_{2} \mathrm{O}$ and, thus, the $f \mathrm{O}_{2}$ (e.g., Scaillet et al. 1995). These experiments aim to answer the question of whether extensive hydrothermal influence and, thus, water-saturated conditions are required to produce anatectic melts at the AML roof. Additionally, two experimental series were performed at higher pressure (i.e. $200 \mathrm{MPa}$ ) at $\mathrm{T}=1000$ and $1030^{\circ} \mathrm{C}$ to test the pressure influence on phase stabilities (corresponding to $\sim 6 \mathrm{~km}$ crustal depth). The pressure was monitored with a strain gauge manometer with an uncertainty of $\pm 5 \mathrm{MPa}$. The temperature range over the sample was $\pm 10^{\circ} \mathrm{C}$. Experimental run products (six capsules with the six different starting materials were run at the same time) were isobarically quenched, using a rapid quench unit. All experimental conditions are listed in Table 2 and the detailed setup of the rapid-quench IHPV that was used is described in Berndt et al. (2002).

\section{Electron-probe micro analyzer (EPMA)}

Experimental products (glass and minerals) were analyzed with the Cameca SX 100 electron microprobe in Hannover. For minerals, we used $15 \mathrm{kV}$ high voltage, $15 \mathrm{nA}$ beam current, 10 
seconds counting time on peak and 10 seconds on background, and a focused beam. For analysis of water-bearing glasses, which is problematic due to "alkali-loss" effects (e.g., Morgan and London 2005), a special procedure was applied following Koepke et al. (2004). The beam current was set to $4 \mathrm{nA}$ and the counting time varied for the different elements; $4 \mathrm{~s}$ for $\mathrm{K}, 8 \mathrm{~s}$ for $\mathrm{Si}, \mathrm{Al}$, Ti, and $\mathrm{Fe}, 10 \mathrm{~s}$ for $\mathrm{Na}$ and $\mathrm{Zr}, 12 \mathrm{~s}$ for $\mathrm{Mg}, 16 \mathrm{~s}$ for $\mathrm{Ca}$, and $30 \mathrm{~s}$ for $\mathrm{Ba}$, $\mathrm{P}, \mathrm{S}, \mathrm{Cl}$, and $\mathrm{Mn}$. Alkalis were measured first. Background counting time was always the same as peak counting time. Whenever possible, a defocused beam with a spot size of 5,10 , or $20 \mu \mathrm{m}$ was used, and $\mathrm{Na}$ loss was checked by comparing the results of measurements with different beam sizes on identical glasses of an experimental sample with larger melt pools. Standard glasses with compositions similar to the experimental glasses and with known water contents have been used for estimating water contents in experimental glasses by applying the "by-difference" method (e.g., Devine et al. 1995). Even though the uncertainties are relatively high ( \pm 0.5-0.7 wt\% according to Parat et al. 2008), the application of the "by-difference" method controls the problem of small melt pools precluding water determination with a direct method such as infrared spectroscopy. With known melt composition and water content the $a \mathrm{H}_{2} \mathrm{O}$ was calculated following the thermodynamic model of Burnham (1981) for a given water solubility in a melt subjected to known pressure (major effect) and temperature (minor effect).

\section{RESULTS}

\section{Attainment of equilibrium}

Attainment of global equilibrium in partial-melting experiments is strongly dependent on the grain size (see review of Johannes and Koepke 2001). The use of fine-grained starting material (i.e. $\leq 10 \mu \mathrm{m}$ ) enhances the chance of achieving overall equilibrium. However, in-situ analyses of newly-formed experimental phases are virtually impossible due to tiny crystals and melt pools (e.g., Koepke et al. 2003). Consequently, here we use a relatively large grain 
size of 125-200 $\mu \mathrm{m}$. As expected, in some experiments cores of unaffected starting material are still present after the experiment (e.g. clinopyroxene at $\mathrm{D} 11$ and $\mathrm{T} \leq 970^{\circ} \mathrm{C}$, Fig. 2). However, longer run durations (i.e. several weeks) did not guarantee that residual mineral cores in the starting material would dissolve (e.g., Wolf and Wyllie 1994; Johannes and Koepke 2001). The partial melting experiments of Johannes and Koepke (2001) used a starting material with a grain size of $\sim 10 \mu \mathrm{m}$; even after 36 days, unreacted cores of the starting material were observed. Thus, the possibility of disequilibrium melting and the subsequent effect on interpretation of results should be considered. Wolff et al. (2013) addressed the potentially unsystematic effects caused by unreacted starting material cores which do not take part in the general melting reaction on both phase relations and phase compositions. Because the effect is strongest at low temperatures, this should be considered when comparing low-temperature runs with those performed at higher temperature. However, the achievement of at least local equilibrium in our experiments is supported by several observations: (1) Compositions of newly-formed mineral phases, both as isolated crystals and as rim growth, are homogeneous within a sample, i.e., no zonation in newly-formed phases; (2) newly-formed crystals at higher temperature (e.g., olivine at $\geq 1000^{\circ} \mathrm{C}$ ) are commonly euhedral; at lower temperatures plagioclase forms sponge-like grains that are homogenous in composition and widely infiltrated by melts (e.g., D10 at $970^{\circ} \mathrm{C}$ in Fig. 2); (3) all phase compositions vary systematically with temperature, and compositional trends are consistent with trends expected from the literature; and (4) melt compositions vary systematically with temperature and are homogeneous within each experiment.

Experiments close to the solidus using altered dikes as starting materials (D10 and D11) were duplicated with mm-sized pieces of the starting material in order to obtain melt pools large enough for de-focused EPMA measurements. It is obvious that the conditions of these experiments are far away from global equilibrium conditions. However, when comparing phase compositions (melt and minerals) of these experiments with those performed with a 
fine-grained powder under the same conditions, it can be stated that they are identical within analytical error. Such an experimental procedure has previously been shown to be suitable (Wolff et al. 2013).

\section{Phase Relations}

Phase relations of the experiments are illustrated in Figure $3 \mathrm{a}$ and highlighted with backscattered electron (BSE) images for starting material D11 at different temperatures and for all starting compositions at $970^{\circ} \mathrm{C}$ in Figure 2 (see also experimental conditions in Table 2). Each experiment was analyzed with ImageJ image processing and analysis software (Schneider et al. 2012) which determined solid phase and melt proportions using BSE image grey scales. In most experiments, the residual assemblage is composed of clinopyroxene + plagioclase (except for GD14 at $\mathrm{T}=1030^{\circ} \mathrm{C}$ ) + titanomagnetite (except for D10, D11, and GF45 at $\mathrm{T}=1030^{\circ} \mathrm{C}$ ). Ilmenite is stable in all runs at $\mathrm{T} \leq 970^{\circ} \mathrm{C}$. Olivine occurs only at higher temperatures (variable from $940^{\circ} \mathrm{C}$ to $1000^{\circ} \mathrm{C}$ ) and replaces orthopyroxene. Orthopyroxene and olivine only coexist in the GF36 composition at $\mathrm{T}=970^{\circ} \mathrm{C}$. The reaction from orthopyroxene to olivine with increasing temperature is crucial because this relation can be used for constraining the temperature of granoblastic hornfels formation, since the natural rocks are in general orthopyroxene-bearing and practically free of olivine. Olivine is present in most of our experiments at $\mathrm{T} \geq 970^{\circ} \mathrm{C}$ except for in sample $\mathrm{D} 11$ (only present at $\mathrm{T}=1030^{\circ} \mathrm{C}$ ) and for GF45 (only present at $\mathrm{T} \geq 1000^{\circ} \mathrm{C}$ ), implying that the formation temperatures of the natural granoblastic lithologies were generally below $1000^{\circ} \mathrm{C}$.

Although most experiments were water saturated, amphibole is absent in all experimental products. This is in contrast to Beard and Lofgren (1991) who produced strongly peraluminous water-saturated melts that coexisted with an amphibole-rich residual assemblage. Such a scenario is also observed in granoblastic rocks from the Troodos ophiolite where amphiboles occur as interstitial crystals and are interpreted to be magmatic (Gillis and 
Coogan 2002). However, magmatic amphiboles are not observed in granoblastic rocks from Site 1256. Moreover, results of our study show that for the boundary conditions applied here, amphibole is not a required phase for the residue, implying that the absence of amphibole in natural granoblastic hornfels does not necessarily indicate that these rocks were formed under low $a \mathrm{H}_{2} \mathrm{O}$. Phase relations and reactions for the starting materials that were used are formulated in Table 3 in order to emphasize the temperature at which the anhydrous granoblastic mineral assemblage could be reproduced.

Additionally, for one experimental series at $\mathrm{T}=1000^{\circ} \mathrm{C}$ and $100 \mathrm{MPa}$, beside water, a second fluid phase $\left(\mathrm{CO}_{2}\right)$ was added in order to test the effect of lower $a \mathrm{H}_{2} \mathrm{O}(<0.5)$ on phase relations and composition. As expected, a reduced $a \mathrm{H}_{2} \mathrm{O}$ shifted the solidus temperature to significantly higher values. The phase relations and modal fractions of this experiment ( 20 vol\% melt, $\sim 40$ vol\% plagioclase, $\sim 30$ vol\% pyroxenes, $\sim 10$ vol\% Fe-Ti oxides; Fig. 3a) is very similar to the corresponding run performed under water saturation at $\mathrm{T}=940^{\circ} \mathrm{C}$. Hence, runs with "dry" granoblastic hornfels as starting material (GF36, GF45) are below the solidus under a reduced $a \mathrm{H}_{2} 0$. Crystallization of $\mathrm{Fe}-\mathrm{Ti}$ oxides proceeds at significantly higher temperatures in waterundersaturated experiments compared to the corresponding experiments at water saturation, which is probably due to the more reduced redox conditions at lower $a \mathrm{H}_{2} 0$ (e.g., Berndt et al. 2005) which destabilizes Fe-Ti oxides.

In addition to the $100 \mathrm{MPa}$ experiments, two runs $\left(\mathrm{T}=1000^{\circ} \mathrm{C}\right.$ and $\left.1030^{\circ} \mathrm{C}\right)$ were performed at $200 \mathrm{MPa}$ and water-saturated conditions in order to study the influence of pressure on phase assemblages. Pressure is expected to influence phase relations because fluid and water solubilities are strongly dependent on pressure (e.g., Holtz et al. 1992, 2001; Berndt et al. 2002). Previous crystallization experiments have shown that the main pressure effect is the shift of plagioclase saturation to lower temperatures (e.g., Feig et al. 2006). Accordingly, plagioclase crystallization was suppressed in runs performed at $200 \mathrm{MPa}$, while remaining 
stable in all comparable experiments at $100 \mathrm{MPa}$ (Fig. 3a). The $200 \mathrm{MPa}$ pressure (equivalent to $\sim 6 \mathrm{~km}$ depth) represents an unrealistic depth for the AML roof at the fast-spreading EPR, but may be suitable for slower spreading-rates (e.g. 5-7 km depth at the Mid-Atlantic Ridge; Wilson et al. 2006; McCaig and Harris 2012). Thus, experiments at higher pressure provide important preliminary data on the phases occurring in this geological setting, where coupled magmatic-hydrothermal interactions have already been recognized (McCaig and Harris 2012).

\section{Composition of the anatectic melts}

The degree of partial melting (melt fraction F; see Figure 3b) is, as expected, strongly temperature dependent but also varies significantly with the starting material. The first melts of D10 and D11, analyzable by EPMA, occur at $\mathrm{T}=910^{\circ} \mathrm{C}(\mathrm{F} \approx 10-20 \mathrm{vol} \%)$. First melts of GD12 and GD14 occur at $\mathrm{T}=940^{\circ} \mathrm{C}\left(\mathrm{F} \approx 10-20\right.$ vol\%), and of GF36 and GF45 at $\mathrm{T}=970^{\circ} \mathrm{C}(\mathrm{F}$ $\approx 10 \mathrm{vol} \%$ ). This trend is in agreement with the increasingly refractory character of the starting material, varying from altered sheeted dikes (D10, D11) to partially re-crystallized (GD12, GD14) to fully re-crystallized granoblastic hornfels (GF36, GF45). The first melts of D10 and D11 are high in $\mathrm{SiO}_{2}$ contents at 70.7 and $72.0 \mathrm{wt} \%$, respectively. The first GD12 and GD14 melts $=67.4$ and $68.4 \mathrm{wt} \% \mathrm{SiO}_{2}$, respectively, while GF36 and GF45 are less evolved (61.7 and 61.9 wt\% $\mathrm{SiO}_{2}$, respectively; Fig. 4, left column). Melt compositional evolution with increasing melt fraction and temperature is consistent for all starting materials and follows the expected trend (i.e. towards the bulk rock composition; Fig. 4 and Tab. 4).

In order to better track the effect of the different protoliths on the extent of enrichment or depletion with regard to the different elements at different melting degrees (or temperatures), all melt compositions were normalized to the starting material composition (Fig. 4, right column). These plots show that the degree of enrichment or depletion of a specific element in the melt is distinctly different depending on the protolith. A strong discrepancy between the 
different protoliths, even within the same lithological subtype (D10 compared to D11 and GD12 compared to GD14), is distinctive for $\mathrm{Al}_{2} \mathrm{O}_{3}$ and the alkalis, which are mainly controlled by plagioclase crystallization (present in all experiments at $100 \mathrm{MPa}$ except for GD14 at $\mathrm{T}=1030^{\circ} \mathrm{C}$ ). With respect to $\mathrm{Al}_{2} \mathrm{O}_{3}$, starting material $\mathrm{D} 11$ is characterized by an increase with increasing temperature, while GD12, GF36, and GF45 decrease. D10 and GD14 increase initially up to $\mathrm{T}=970^{\circ} \mathrm{C}$ followed by a slight decrease at higher temperature. $\mathrm{Al}_{2} \mathrm{O}_{3}$ in $\mathrm{D} 11$ is $\sim 2.0 \mathrm{wt} \%$ lower at $\mathrm{T} \leq 970^{\circ} \mathrm{C}$ than are all other compositions, resulting in a weak enrichment when normalized to the starting material, while D10 is strongly enriched (Fig. 4). $\mathrm{K}_{2} \mathrm{O}$ is generally low in all experiments due to low concentrations in the protolith. However, the behavior for varying degrees of melting is significantly different. Although the $\mathrm{K}_{2} \mathrm{O}$ content is relatively constant for the anatectic melts of the altered basalt, anatectic melts of one "hydrous" (GD12) and one "dry" (GF45) granoblastic hornfels are strongly enriched with initial melting; this is clearly shown when normalized to the starting material (Fig. 4). In contrast, $\mathrm{Na}_{2} \mathrm{O}$ is only subtly lowered with increasing temperature within individual samples even though the variation between the different protoliths is significant (Fig. 4). Moreover, the normalized starting material diagram for $\mathrm{Na}_{2} \mathrm{O}$ reveals the challenge of achieving global equilibrium in partial melting experiments. The normalized value of sample D10 at $\mathrm{T}=940^{\circ} \mathrm{C}$ is far from the trend, suggesting that in this experiment the number of relict phases is particularly high. However, as this is the only obvious outlier, it can be assumed that, although present, relict phases in other experiments have less influence over the chemical composition of the melt.

$\mathrm{TiO}_{2}$ and $\mathrm{FeO}$ in the melt are strongly affected by a decrease in magnetite and ilmenite crystallization with increasing temperature. $\mathrm{TiO}_{2}$ exhibits relatively constant increases up to $\mathrm{T}=1000^{\circ} \mathrm{C}$ where the highest content can be observed, followed by a slight decrease at higher temperature (Fig. 4). This peak is due to the absence of ilmenite at $\mathrm{T} \geq 1000^{\circ} \mathrm{C} . \mathrm{P}_{2} \mathrm{O}_{5}$ contents in the melt (see Fig. 7c in the Discussion) are generally below 0.4 wt\% except for GD12 and 
GD14 at $\mathrm{T}=970^{\circ} \mathrm{C}$ where an increase of up to $0.62 \mathrm{wt} \%$ is observed. $\mathrm{Cl}$ content in the melt (see Fig. 7d), which can be used as a tracer for sea water contamination due to hydrothermal circulation, is strongly dependent upon the $\mathrm{Cl}$ contents of the starting material (1000 ppm for GD12, 300-600 ppm for all others, Table 1) and is accordingly highest in the first melt using the GD12 starting material, reaching $0.91 \mathrm{wt} \%$ in the run performed at $\mathrm{T}=940^{\circ} \mathrm{C}$ (for a detailed description and illustration of $\mathrm{Cl}$ and $\mathrm{P}_{2} \mathrm{O}_{5}$ see section "Comparison of the experimental melts with felsic rocks from Site 1256" in the Discussion).

Experiments at $\mathrm{T}=1000^{\circ} \mathrm{C}$ with water-undersaturated samples (i.e. $\sim 0.8 \mathrm{wt} \% \mathrm{H}_{2} \mathrm{O}, a \mathrm{H}_{2} \mathrm{O} \sim 0.1$ for D10; $\sim 2.0 \mathrm{wt} \% \mathrm{H}_{2} \mathrm{O}, a \mathrm{H}_{2} \mathrm{O} \sim 0.45$ for D11, GD12, and GD14) at $100 \mathrm{MPa}$ correspond in terms of melt fraction and mineral proportions to those performed at $\mathrm{T}=940^{\circ} \mathrm{C}$ at water saturation (Fig. 3). Thus, GF36 and GF45 are below the solidus. D10 contains $65.7 \mathrm{wt} \% \mathrm{SiO}_{2}$ at $a \mathrm{H}_{2} \mathrm{O} \sim 0.1$, while it shows minor enrichment at $a \mathrm{H}_{2} \mathrm{O} \sim 0.45$ with variations between 54.9 and $58.9 \mathrm{wt} \% . \mathrm{Al}_{2} \mathrm{O}_{3}$ is distinctively lower at reduced $a \mathrm{H}_{2} \mathrm{O}$ resulting in contents from 11.3 to $14.4 \mathrm{wt} \%$, in each case close to the starting material (Fig. 4). The FeO content at waterundersaturated conditions is notably higher, resulting in a potentially higher degree of $\mathrm{Fe}$ oxide crystallization (e.g., magnetite) at lower temperature, while $\mathrm{TiO}_{2}$ is only slightly affected by reduced $a \mathrm{H}_{2} \mathrm{O}$ and, thus, more reducing conditions. $\mathrm{P}_{2} \mathrm{O}_{5}(0.4$ to $1.0 \mathrm{wt} \%)$ and $\mathrm{Cl}$ ( 0.1 to $0.8 \mathrm{wt} \%)$ are higher in all water-undersaturated experiments than in water-saturated experiments (see Fig. 7).

$200 \mathrm{MPa}$ experiments (at $\mathrm{T}=1000$ and $1030^{\circ} \mathrm{C}$ ) display a high melt fraction (from 70 to 94 vol\%) triggered by the higher water content (4.5 to $5.1 \mathrm{wt} \%)$ in the melt at higher pressure (Berndt et al. 2002). This results in a melt composition similar to that of the starting material. $\mathrm{SiO}_{2}$ contents do not exceed $54.4 \mathrm{wt} \%$ and the $\mathrm{Al}_{2} \mathrm{O}_{3}$ content is too low to crystallize plagioclase, in contrast to experiments at shallower pressure (i.e., $100 \mathrm{MPa}$ ).

\section{Compositions of newly-formed mineral phases}


The average mineral compositions of the starting materials and the corresponding experiments are presented in Table 4. In most experiments, at low temperature and correspondingly low melt fraction, the assemblages and the compositions of the newly-formed minerals correspond to those of the natural granoblastic hornfels from the IODP Site 1256 or the Oman ophiolite dike/gabbro transition (e.g., Koepke et al. 2008; Alt et al. 2010; France et al. 2010; Zhang et al. 2014). At higher temperature and higher melt fraction, orthopyroxene is often replaced by minor amounts of olivine, which is not present in natural granoblastic hornfels. Because olivine is absent in all starting materials it is always newly formed. It is stable at $\mathrm{T} \geq 970^{\circ} \mathrm{C}$, except for starting material GF45 $\left(\geq 1000^{\circ} \mathrm{C}\right)$ and D11 (only at $1030^{\circ} \mathrm{C}$ ) and mostly forms euhedral crystals (see BSE images in Fig. 2). Forsterite contents increase with temperature from $61.2 \mathrm{~mol} \%\left(\mathrm{GD} 14\right.$ at $970^{\circ} \mathrm{C}$ ) to $76.8 \mathrm{~mol} \%\left(\mathrm{GD} 12\right.$ at $\left.1030^{\circ} \mathrm{C}\right)$. All other olivine-bearing experiments fall within this range.

Newly formed clinopyroxenes are present in all experiments at $100 \mathrm{MPa}$ both at the rim of residual protolith clinopyroxenes and as isolated euhedral crystals (see BSE images in Fig. 2) Compositions are always homogeneous within individual experimental runs. The application of the Al-in-clinopyroxene thermometer of France et al. (2010), which was calibrated in a comparable system, reveals good agreement with the experimental temperature. While $\mathrm{TiO}_{2}$ is in a narrow range within all experiments using one starting material (Fig. 5), $\mathrm{Al}_{2} \mathrm{O}_{3}$ and $\mathrm{Mg \#}$ $\left(\mathrm{Mg} \#=\mathrm{Mg} /\left(\mathrm{Mg}+\mathrm{Fe}_{\text {total }}\right)\right)$ continuously increase with temperature from $\mathrm{Al}_{2} \mathrm{O}_{3}=1.35 \mathrm{wt} \%$ and $\mathrm{Mg} \#=65\left(\mathrm{D} 10\right.$ at $\left.910^{\circ} \mathrm{C}\right)$ to $\mathrm{Al}_{2} \mathrm{O}_{3}=3.19 \mathrm{wt} \%$ and $\mathrm{Mg} \#=87\left(\mathrm{D} 10\right.$ at $\left.1030^{\circ} \mathrm{C}\right)$. Clinopyroxene compositions of all other experiments fall within this range. Orthopyroxene typically grows at the rim of clinopyroxene relics and only rarely forms euhedral crystals. $\mathrm{Mg \#} \mathrm{(62.3} \mathrm{to} 70.0), \mathrm{Al}_{2} \mathrm{O}_{3}$ (0.90 to $\left.1.45 \mathrm{wt} \%\right), \mathrm{TiO}_{2}(0.25$ to $0.34 \mathrm{wt} \%)$, and $\mathrm{CaO}$ (1.71 to $2.21 \mathrm{wt} \%$ ) increase systematically with temperature, best demonstrated by sample D11, where orthopyroxene is stable over the widest temperature range (i.e. from $910^{\circ} \mathrm{C}$ to $1000^{\circ} \mathrm{C}$ ). 
Plagioclase is present in all $100 \mathrm{MPa}$ experiments (except for GD14 at $\mathrm{T}=1030^{\circ} \mathrm{C}$ ). It occurs either as euhedral crystals or as rim overgrowths around relic cores. The Anorthite (An) content (in mol\%) varies systematically with temperature with an average increase of $<2$ $\% / 10^{\circ} \mathrm{C}$ for D11 and up to $\sim 5 / 10^{\circ} \mathrm{C}$ for GF36 and GF45. An contents vary up to $20 \mathrm{~mol} \%$ between the different protolith compositions at the same temperature (Fig. 6). The $\mathrm{FeO}_{\mathrm{t}}$ content of plagioclase increases with temperature coinciding with the increase of $\mathrm{FeO}_{\mathrm{t}}$ in the melt, up to $1.39 \mathrm{wt} \%\left(\mathrm{D} 10\right.$ at $\left.1000^{\circ} \mathrm{C}\right)$. In D10 and D11 metastable An was observed. As previously proposed by France et al. (2010) this phase may form during the breakdown of prehnite, which is present as an alteration phase in the starting material, following the reaction:

1 prehnite $\leftrightarrow 2$ anorthite +1 wollastonite $+\mathrm{H}_{2} \mathrm{O}$.

Titanomagnetite is present in all experimental runs up to $\mathrm{T}=1000^{\circ} \mathrm{C}$ and, additionally, in GD12, GD14, and GF36 at $\mathrm{T}=1030^{\circ} \mathrm{C}$. $\mathrm{TiO}_{2}$ content varies between $9.09 \mathrm{wt} \%$ (GF36) and $16.52 \mathrm{wt} \%$ (D10). Ilmenite is only present in experiments up to $\mathrm{T}=970^{\circ} \mathrm{C}$; its $\mathrm{Al}_{2} \mathrm{O}_{3}$ content is generally relatively low $\left(\leq 0.5 \mathrm{wt} \%\right.$, except for $\mathrm{D} 11$ at $\left.\mathrm{T}=910^{\circ} \mathrm{C}\right)$, while $\mathrm{MgO}$ uniformly increases with temperature (from 2.79 to $4.99 \mathrm{wt} \%$ ).

Elevated pressure (i.e. $200 \mathrm{MPa}$ ) has only a minor effect on the composition of the crystallized phases when compared to experiments at the same temperature at $100 \mathrm{MPa}$. Lower $a \mathrm{H}_{2} \mathrm{O}(<0.5)$ influences the chemistry of crystallized phases; this is mainly due to the change to more reducing conditions. Olivine equilibrates at higher $\mathrm{FeO}$ contents (from +6 to +16 wt $\%$ ), and, thus, to lower $\mathrm{Mg \#}$ (down to 24 units lower). FeO in clinopyroxene and, in particular, orthopyroxene is also enriched (up to $11 \mathrm{wt} \%$ higher) compared to all other experiments at $a \mathrm{H}_{2} \mathrm{O}=1$, while plagioclase compositions transform to more evolved compositions that correspond to experiments performed at lower temperatures under water- 
saturated conditions. The $\mathrm{Fe}^{2+} / \Sigma \mathrm{Fe}$-ratio calculated for oxides is lower at water-saturated conditions (e.g., for D10: $\mathrm{Fe}^{2+} / \Sigma \mathrm{Fe}=0.8-0.9$ at $a \mathrm{H}_{2} \mathrm{O} \sim 0.1$, and $\mathrm{Fe}^{2+} / \Sigma \mathrm{Fe}=0.5$ at $a \mathrm{H}_{2} \mathrm{O}=1$ ).

\section{DISCUSSION}

\section{Influence of the starting material composition on anatectic products}

One of the main objectives of the present study was to evaluate the influence of the starting material composition (modal and chemical) on the modal and chemical composition of experimental results. Our results will be compared hereafter to France et al. (2010), who examined partial melting effects of a fully altered dike from the Oman ophiolite, and to selected experiments of Beard and Lofgren (1991), who studied the anatexis of greenschist and hornblende hornfels at $100 \mathrm{MPa}$. As a whole, anatectic melts produced in the present study display lower $\mathrm{SiO}_{2}$ concentrations than melts produced at similar temperatures by Beard and Lofgren (1991) (Fig. 7). This is probably related to the more primitive and less altered character of our starting material. However, this discrepancy with our experimental melts is limited to higher temperature (or high partial melting degree). It is less pronounced for Beard and Lofgren's (1991) first dry anatectic melts at lower temperature (i.e. $\leq 970^{\circ} \mathrm{C}$ ), whereas their low temperature wet partial melts remain at relatively low $\mathrm{SiO}_{2}$. This is due to a distinctively higher melt fraction with added water $\left(+10\right.$ to 15 vol $\%$ at $\left.\mathrm{T}=950^{\circ} \mathrm{C}\right)$. However, in experiments with low melt fraction at temperatures close to the solidus $\left(\sim 900^{\circ} \mathrm{C}\right)$ all anatectic melts (wet and dry) of Beard and Lofgren (1991), France et al. (2010), and altered basalts from this study (D10, D11) exhibit $\mathrm{SiO}_{2}$ contents in a similar range ( 70 to $75 \mathrm{wt} \%$ ).

The alteration of protoliths mainly influences the melt composition for minor elements that are particularly sensitive to hydrothermal alteration (e.g., $\mathrm{K}, \mathrm{Cl}$ ). As an example, the observed enrichment in $\mathrm{K}_{2} \mathrm{O}$ is highly sensitive to the $\mathrm{K}_{2} \mathrm{O}$ content of the starting material. Anatectic melts are generally $\mathrm{K}_{2} \mathrm{O}$-poor in our results (starting material $\mathrm{K}_{2} \mathrm{O} \sim 0.1 \mathrm{wt} \%$ ), and strongly 
enriched in France et al. (2010) and Beard and Lofgren (1991); i.e., starting material $\mathrm{K}_{2} \mathrm{O}=0.20$ and $0.16 \mathrm{wt} \%$, respectively. $\mathrm{K}_{2} \mathrm{O}$ can be enriched in the starting material due to alteration by seawater circulation, which is in agreement with the fully altered character of the France et al. (2010) starting material and the amphibole rich/pyroxene poor starting materials of Beard and Lofgren (1991).

Although $\mathrm{K}_{2} \mathrm{O}$ in sample GD12 $(0.09 \mathrm{wt} \%)$ is similar to that in the other starting materials used it is significantly enriched in the first melts. That is not the case for the five other samples used in this study (Fig. 7b) which also include potentially different melt fractions. Despite low $\mathrm{K}_{2} \mathrm{O}$ in the protolith, GD12 generally shows the strongest alteration imprint. This is expressed by the substitution of clinopyroxene for secondary amphibole. GD12 also shows the highest $\mathrm{Cl}$ concentration in the protolith $(0.10 \mathrm{wt} \%)$, potentially caused by rock/seawater interaction during hydrothermal alteration with the consequence that $\mathrm{Cl}$ contents of the anatectic melts leads to the most pronounced enrichment trend (Fig. 7d). The same effect is obvious for phosphorous, where the protolith with the highest $\mathrm{P}_{2} \mathrm{O}_{5}$ (GD12) shows the strongest enrichment in the experimental melts (Fig. 7c). However, the concentration of $\mathrm{Cl}$ and $\mathrm{P}_{2} \mathrm{O}_{5}$ in protolith GD12 is relatively small compared to the average of $\mathrm{Cl}$ and $\mathrm{P}_{2} \mathrm{O}_{5}$ in the D10, D11, and GD14 protoliths ( $\mathrm{Cl}: 0.10$ to $0.05 ; \mathrm{P}_{2} \mathrm{O}_{5}: 0.17$ to 0.12 ; see Table 1$)$. Moreover, despite the distinctive altered character of France et al.'s (2010) starting material, that material is low in $\mathrm{P}_{2} \mathrm{O}_{5}(0.12 \mathrm{wt} \% ; \mathrm{Cl}$ not given) and their experimental melts show only moderate enrichment trends for both $\mathrm{Cl}$ and $\mathrm{P}_{2} \mathrm{O}_{5}$. Thus, the degree to which the protoliths have been altered seems to have a minor influence on the concentration of phosphorus in anatectic melts, but rather the effective concentration of phosphorus in the starting material phase assemblages. Consequently, $\mathrm{P}_{2} \mathrm{O}_{5}$ concentration in the melt is dominated by the amount of apatite and the degree of apatite melting. Although $\mathrm{Cl}$ is slightly enriched in GD12, an additional influence of the alteration degree on strong $\mathrm{Cl}$ enrichment is likely to be the major source for elevated $\mathrm{Cl}$ contents in seafloor alteration. 
The MORB normalized diagram (Gale et al. 2013) of all oxides for experiments with a melt fraction $\leq 20$ vol\% highlights the different influence of our starting materials and those of Beard and Lofgren (1991) and France et al. (2010) on the generated melts (Fig. 8). Anatectic melts from other experimental studies generally exhibit lower MORB normalized values and are distinctly enriched in $\mathrm{K}_{2} \mathrm{O}$. Moreover, a different evolution in MORB normalized values is apparent for France et al.'s (2010) anatectic melts which exhibit a step from low $\mathrm{TiO}_{2}$ to enriched $\mathrm{Al}_{2} \mathrm{O}_{3}$, followed by low values for $\mathrm{FeO}, \mathrm{MgO}$, and $\mathrm{CaO}$ and strong enrichment in $\mathrm{Na}_{2} \mathrm{O}$ and $\mathrm{K}_{2} \mathrm{O}$ finalized by pronounced low $\mathrm{P}_{2} \mathrm{O}_{5}$ values. This deviation from the anatectic melts of this study highlights again the difference between the Oman ophiolite protolith used by France et al. (2010) and the IODP Site 1256 protoliths used in this study.

The large span in crystallized plagioclase composition is also reflected in the difference in the starting materials (Fig. 6). In experiments at a given temperature, the spread in An values is $20 \mathrm{~mol} \%\left(\mathrm{~T} \leq 940^{\circ} \mathrm{C}\right)$, caused by varying $\mathrm{Ca} / \mathrm{Na}$ ratios of the different starting materials (D11 $>$ D10; GD12 > GD14). This spread decreases with increased temperature, revealing a deviation of only $6 \mathrm{~mol} \%$ at $1030^{\circ} \mathrm{C}$ at generally high An values (>80 mol\%).

\section{Temperature evolution through the sheeted dike complex root zone}

Equilibrium temperatures of the peak metamorphic overprint recorded by two-pyroxene thermometry (Brey and Koehler 1990; Andersen et al. 1993) of pyroxene hornfels, sampled at the AML roof either in modern oceanic crust or in ophiolites, give an estimation of temperatures of the anatectic processes in the dike/gabbro transition (e.g. Gillis and Coogan 2002; Gillis 2008; Koepke et al. 2008; Alt et al. 2010; Koepke and Goetze, in press). Temperature calculations of granoblastic rocks from Hess Deep, for example, result in an average temperature of 900 to $950^{\circ} \mathrm{C}$ (Gillis 2008), perfectly matching the temperatures of our experiments for relatively small melt fractions, which produce highly-evolved partial melts under water-saturated conditions. Similar values were estimated for hornfels from the 
Troodos and Oman ophiolite dike/gabbro transitions (e.g., $\mathrm{T}=850-1050^{\circ} \mathrm{C}$; Gillis and Coogan 2002; Gillis 2008). Amphibole-plagioclase thermometry generally yields lower temperatures for the studied sample suites $\left(400-700^{\circ} \mathrm{C}\right)$, reflecting the record of hydrothermal alteration at relatively high temperatures (amphibolite facies) mainly after the contact metamorphic overprint (Gillis and Coogan 2002; Gillis 2008; Alt et al. 2010).

For two-pyroxene hornfels of the dike/gabbro transition penetrated at Site 1256, several studies deal with the temperature evolution of this particular zone (Koepke et al. 2008, 2011; France et al. 2009; Alt et al. 2010; Zhang et al. 2014). While Alt et al. (2010) applied the twopyroxene thermometer of Brey and Koehler (1990) and report equilibrium temperatures of $800^{\circ} \mathrm{C}-924^{\circ} \mathrm{C}$, the QUILF two-pyroxene thermometer of Andersen et al. (1993) applied by Koepke et al. (2008, 2011) and France et al. (2009) determined distinctly higher temperatures for the peak metamorphic overprint $\left(935^{\circ} \mathrm{C}-1045^{\circ} \mathrm{C}\right)$, where the metamorphic grade is highest (presence of two-pyroxene hornfels). In those granoblastic hornfels from the Site 1256 dike/gabbro transition, which underwent hydrothermal alteration after the metamorphic imprint, amphiboles are ubiquitous, enabling the application of amphibole thermometers (i.e., plagioclase-amphibole by Holland and Blundy 1994, and Ti-in-amphibole by Ernst and Liu 1998). As noted above, results reveal distinctly lower equilibrium temperatures for this event. Koepke et al. (2008) obtained temperatures of $708^{\circ} \mathrm{C}-854^{\circ} \mathrm{C}$ and $650^{\circ} \mathrm{C}-747^{\circ} \mathrm{C}$ by using the plagioclase-amphibole thermometer and the Ti-in-amphibole thermometer, respectively. Even though Alt et al. (2010) calculated temperatures with the Ti-in-amphibole thermometry of up to $913^{\circ} \mathrm{C}$ for individual samples, the majority of estimated temperatures are significantly lower, consistent with the hypothesis that hornfels cooling proceeded under hydrous conditions due to seawater-derived hydrothermal circulation.

\section{Comparison of the experimental melts with felsic rocks from IODP Site 1256}


The great advantage of using IODP Site 1256 samples as starting material is that experimental melts and residues can be directly compared to their natural equivalents. The compositions of mm-to-cm-thick felsic veins, consisting of tonalites cutting granoblastic hornfels in the drill core from Site 1256, are used for comparison. These are regarded as products of in-situ partial melting of AMC roof basalts (Koepke et al. 2008, Alt et al. 2010, Zhang et al. 2014). In Figure 7 we also included the compositions of small felsic veins cutting hornfels sampled from the dike/gabbro transitions of the southern Oman Semail ophiolite blocks (Freund 2014); these are also regarded as anatectic melts generated in the roof rocks of AMLs (France et al. 2009, 2014). It is important to note that plagiogranites in the Oman ophiolite, in general, are very heterogeneous in composition and size and are believed to have been formed by different processes (i.e., fractional differentiation of wet, subduction-zone related basalt or melting of sediments from the subducted slab (Rollinson 2009; Haase et al. 2015).

The relatively wide compositional range of the Oman felsic veins (i.e. $\mathrm{SiO}_{2} \sim 58-77 \mathrm{wt} \%$ ) covers the complete range of $\mathrm{SiO}_{2}$ contents of the experimental results at $\mathrm{T} \leq 970^{\circ} \mathrm{C}$ (Fig. 7). While most major and minor elements of the experimental melts with relatively low melt fraction $(\leq 20 \mathrm{vol} \%)$ fit quite well with $1256 \mathrm{D}$ tonalites, there is a large discrepancy with respect to $\mathrm{Al}_{2} \mathrm{O}_{3}$ (Fig. 7). While the Oman plagiogranites show $\mathrm{Al}_{2} \mathrm{O}_{3}$ contents similar to those of the experimental melts (Fig. 7), the tonalites from 1256D sampled to date are significantly lower in $\mathrm{Al}_{2} \mathrm{O}_{3}$. $\mathrm{Al}_{2} \mathrm{O}_{3}$ in the melt is mainly influenced by plagioclase crystallization which is, in turn, controlled mainly by the prevailing $a \mathrm{H}_{2} \mathrm{O}$ (e.g., Gaetani et al. 1993; Feig et al. 2006; Koepke et al. 2009). Most of the experiments of this study were performed under watersaturated conditions with $a \mathrm{H}_{2} \mathrm{O}$ close to 1 (i.e. total $\mathrm{H}_{2} \mathrm{O}$ in the melt $\sim 3.5 \mathrm{wt} \%$ ) leading to high $\mathrm{Al}_{2} \mathrm{O}_{3}$ contents in the melt (Fig. 7a), indicating that $1256 \mathrm{D}$ tonalitic melt generation proceeded under vast plagioclase crystallization as a function of reduced $a \mathrm{H}_{2} \mathrm{O}$ (see discussion below). 
$\mathrm{K}_{2} \mathrm{O}$ is very low in $1256 \mathrm{D}$ tonalites and Oman felsic veins $(\leq 0.12 \mathrm{wt} \%$, and $\leq 0.36 \mathrm{wt} \%$, respectively) and, thus, accords with the experimental melt trends except for GD12, which is the sample showing strong hydrothermal alteration (Fig. $7 \mathrm{~b}$ ). While $\mathrm{P}_{2} \mathrm{O}_{5}$ is generally low (0.11 to $0.38 \mathrm{wt} \%)$ for most experimental melts, it is significantly higher in less-evolved $1256 \mathrm{D}$ tonalites $(0.58$ to $0.64 \mathrm{wt} \%)$. Those high values are only observed in samples GD12 and GD14, which show a peak in $\mathrm{P}_{2} \mathrm{O}_{5}$ at intermediate temperature/composition. At higher $\mathrm{SiO}_{2}$ contents $1256 \mathrm{D}$ tonalites have the same $\mathrm{P}_{2} \mathrm{O}_{5}$ range as experimental melts and even mirror the step towards lower $\mathrm{P}_{2} \mathrm{O}_{5}$ between $\mathrm{T}=940^{\circ} \mathrm{C}$ and $910^{\circ} \mathrm{C}$ shown by altered basaltic dikes (Fig. 7c). This is most likely caused by stable apatite in the residue, which in turn would dramatically decrease the content of rare earth elements, $\mathrm{Y}$, and $\mathrm{Sr}$ of the first melts because they are compatible in apatite and apatite is, thus, a trap for $\mathrm{Y}$ and $\mathrm{Sr}$ (Prowatke and Klemme 2006). This would be one explanation for the lower-than-expected trace element enrichments of anatectic melts in comparison to those predicted for melts generated by large extents of fractional crystallization (Brophy 2009; France et al. 2014). Oman plagiogranites are generally low in $\mathrm{P}_{2} \mathrm{O}_{5}(\leq 0.36 \mathrm{wt} \%)$ and are in the range of experimental anatectic melts.

Chlorine concentrations are generally low, even in the very first experimental melts $(\leq 0.35$ wt\%). This is in agreement with 1256D tonalites which are also low in $\mathrm{Cl}$ (max. $0.12 \mathrm{wt} \%$ ) and which are well reproduced by the compositional trend of melts from D11 starting material. Only the melts generated with starting material GD12, which is the sample with the most pronounced secondary alteration, is again out of the range compared to the melts produced by the other protoliths and contains $0.91 \mathrm{wt} \% \mathrm{Cl}$. In Figure $7 \mathrm{~d}$ we also plotted evolved lavas from the $9^{\circ} \mathrm{N}$ overlapping spreading center (OSC) at the EPR (Wanless et al. 2011). Wanless et al.'s (2011) andesitic and dacitic lavas are enriched in $\mathrm{Cl}$ (up to $0.71 \mathrm{wt} \%$ ) and reflect the trend to Cl-enriched experimental melts found in GD12. Wanless et al. (2011) concluded that this enrichment is, in part, due to a combination of partial melting and assimilation of a previously hydrothermalized protolith at the roof of the AML. The results of 
our study show that such $\mathrm{Cl}$ enrichment in anatectic melts is possible, provided that the protoliths are strongly altered, as is the case for sample GD12.

\section{Comparison of the experimental residue with granoblastic hornfels from IODP Site}

\section{6}

As discussed above, in most of our experiments performed at lower temperatures, the residual minerals coexisting with felsic melts are plagioclase, clino- and orthopyroxene, and $\mathrm{Fe}-\mathrm{Ti}$ oxides; exactly the same minerals compose the granoblastic hornfels at the roof of AMLs. In the following, the experimental residual phases are compared with mineral data from natural granoblastic hornfels recovered from Hole 1256D (Koepke et al. 2008; Koepke and Goetze, in press).

With respect to the $\mathrm{TiO}_{2}$ versus $\mathrm{Al}_{2} \mathrm{O}_{3}$ trend (Fig. 5), the high-temperature experiments (i.e. $1000^{\circ} \mathrm{C}$ and $1030^{\circ} \mathrm{C}$ ) show clinopyroxene enrichment in both $\mathrm{TiO}_{2}$ and $\mathrm{Al}_{2} \mathrm{O}_{3}$ in comparison to the starting material. With decreasing temperature, $\mathrm{TiO}_{2}$ and $\mathrm{Al}_{2} \mathrm{O}_{3}$ decrease. For the hydrated basalts as protolith, clinopyroxene compositions at $\mathrm{T}=910^{\circ} \mathrm{C}$ (see example for starting material D10, Fig. 5a) match those of natural "dry" granoblastic hornfels from $1256 \mathrm{D}$, but those from higher temperature deviate significantly. When using the more refractory "hydrous" and "dry" granoblastic hornfels as starting material (GD and GF), clinopyroxenes at all temperatures fit quite well with the clinopyroxene compositions of the natural rocks, except for the highest temperature condition (see examples for starting materials GD14 and GF36, Fig. $5 \mathrm{~b}$ and c). Thus, $\mathrm{TiO}_{2}$ and $\mathrm{Al}_{2} \mathrm{O}_{3}$ in the experimental clinopyroxenes are controlled by both starting material and temperature, if the starting material for the natural processes at the dike/gabbro transitions was already refractory due to previous dehydration processes (corresponding to our GD and GF samples). Our results imply that a partial melting event proceeded at $\mathrm{T}<1030^{\circ} \mathrm{C}$, which is also consistent with the 
composition of the coexisting melt which is too low in $\mathrm{SiO}_{2}$ at $\mathrm{T}>1000^{\circ} \mathrm{C}$ compared to $1256 \mathrm{D}$ tonalites.

The plagioclase compositions in granoblastic hornfels from Site 1256 vary only slightly, between 49 and $56 \mathrm{~mol} \%$ An. The corresponding equilibrium temperatures for the granoblastic hornfels were estimated by the two-pyroxene geothermometer (Koepke et al. 2008; Koepke and Goetze, in press) and are shown in Figure 6. The experimental plagioclases produced with D11 and GD12 starting materials are generally too high in An when compared to the natural hornfelses from Hole $1256 \mathrm{D}$ (Fig. 6), which is a consequence of the high $\mathrm{Ca} / \mathrm{Na}$ ratios in these rocks (see above). Plagioclases from the other starting materials at $\mathrm{T} \leq 970^{\circ} \mathrm{C}$ are within the compositional range of the plagioclases from the natural hornfels. However, all these evaluations are based on experiments performed under water saturation. In the following, we argue that this was probably not the case during the anatectic processes at the roof of the Site 1256 AML.

\section{The role of water activity}

There are several lines of evidence that partial melting processes at the roof of the AML, producing felsic melts and granoblastic hornfels, proceed under reduced $a \mathrm{H}_{2} \mathrm{O}$ rather than at water-saturated conditions.

(I) When comparing the $\mathrm{Al}_{2} \mathrm{O}_{3}$ contents of the experimental melts generated under water-saturated conditions with $1256 \mathrm{D}$ tonalites, it is obvious that the experimental melts contain significantly higher $\mathrm{Al}_{2} \mathrm{O}_{3}$, provided that sampled 1256D tonalites are representative of the partial melt composition (Fig. 7a). Most of our experiments were performed under water saturation; it is wellknown that water surpresses plagioclase stability (e.g., Gaetani et al. 1993; Feig et al. 2006; Koepke et al. 2009), resulting in melts which are strongly 
enriched in $\mathrm{Al}_{2} \mathrm{O}_{3}$ compared to corresponding experiments with reduced $a \mathrm{H}_{2} \mathrm{O}$. However, this enrichment in $\mathrm{Al}_{2} \mathrm{O}_{3}$ relative to starting compositions is not present in experiments performed at $1000^{\circ} \mathrm{C}$ and $a \mathrm{H}_{2} \mathrm{O} \approx 0.5$ (D11, GD12, GD14) and at $a \mathrm{H}_{2} \mathrm{O} \approx 0.1$ (D10) (Fig. 9a). Moreover, the trend of 1256D tonalites is perfectly matched by the strongly water-undersaturated D10 sample $\left(a \mathrm{H}_{2} \mathrm{O} \sim 0.1\right)$. Figure 9a shows that either a very low $a \mathrm{H}_{2} \mathrm{O}$ is required during the anatectic processes (i.e. $a \mathrm{H}_{2} \mathrm{O} \leq 0.1$ ) at $\mathrm{T} \sim 1000^{\circ} \mathrm{C}$ or a moderately-reduced $a \mathrm{H}_{2} \mathrm{O}$ (e.g., $a \mathrm{H}_{2} \mathrm{O} \sim 0.5$ ) is required at $\mathrm{T}<1000^{\circ} \mathrm{C}$. It is important to add a note of caution here, since our database on tonalites from the drilled core at Site 1256 comprises only three samples, a number which is too low to guarantee full representativeness. However, these rocks form a coherent group in terms of petrographic features and geochemical compositions. Thus, we believe that the conclusion drawn here is justified.

(II) The two-pyroxene geothermometer of Andersen et al. (1993) applied to the granoblastic hornfels (data from Koepke et al. 2008; Koepke and Goetze, in press) indicated equilibrium temperatures from 930 to $1045^{\circ} \mathrm{C}$ and is, thus, in accord with scenarios discussed above for very low or moderately-reduced $a \mathrm{H}_{2} \mathrm{O}$. Irrespective of the high $\mathrm{Al}_{2} \mathrm{O}_{3}$ contents, water-saturated melts over this temperature range exhibit a relatively high melt fraction (up to $50 \mathrm{vol} \%$, see Fig. 3b) resulting in $\mathrm{SiO}_{2}$ contents of less than $62 \mathrm{wt} \%$, which are lower than the Site 1256 felsic veins (Fig. 9b). Only by reducing the $a \mathrm{H}_{2} \mathrm{O}$ can higher $\mathrm{SiO}_{2}$ contents at temperatures corresponding to those calculated for the hornfels be reached.

(III) At $\mathrm{T}=1000^{\circ} \mathrm{C}$, which is in the range of natural granoblastic hornfels formation temperatures, experimental An contents match the plagioclase composition 
from the natural hornfels at water-undersaturated conditions (Fig. 6). The best fit at that temperature results from a run with $a \mathrm{H}_{2} \mathrm{O} \sim 0.1$.

(IV) At the equilibrium temperatures estimated for natural granoblastic hornfels (average $\sim 970^{\circ} \mathrm{C}$; Koepke et al. 2008; Koepke and Goetze, in press) in most of our water-saturated experiments, olivine becomes a stable residual phase, crystallizing at the expense of orthopyroxene (Fig. 3a), which is not in accord with the natural phase assemblage where olivine is rare. Despite minor amounts of olivine coexisting with orthopyroxene, our experiments show that reduced $a \mathrm{H}_{2} \mathrm{O}$ leading to lower melt fractions has the same effect as lower temperatures, thus shifting the 'olivine-in' curve to higher temperatures, which is in accord with the natural record.

These observations raise the question of how anatectic processes can occur under strongly water-undersaturated conditions if distinct hydrothermal influence at the dike/gabbro transition is assumed. This is especially true at low degrees of melting, where a small amount of water in the protolith can lead to high $a \mathrm{H}_{2} \mathrm{O}$ in the melt. Hence, for low $a \mathrm{H}_{2} \mathrm{O}$ virtually no water can be present close to the melt lens and water-bearing alteration phases of potential protoliths must lose their water at the initial stage of partial melting. Additionally, pressure fluctuations should be minor because decreasing pressure, caused by an ongoing upward movement of the AML, in turn increases the $a \mathrm{H}_{2} \mathrm{O}$. A possible model (Fig. 10b) allows the hydrothermal flux to penetrate most of the oceanic crust until deep in the sheeted dike complex. However, at a certain distance from the AML ( $\sim 50$ to $100 \mathrm{~m}$ according to Zhang et al. 2014) prevailing conditions hamper water migration deeper into the conducting boundary where anatexis starts. In addition, due to the metamorphic imprint triggered from below by the heat of an advancing melt lens, alteration phases containing $\mathrm{H}_{2} \mathrm{O}$ or $\mathrm{OH}^{-}$groups produced by an earlier hydrothermal alteration lose their water, causing the protolith to become "dry". Hence, for partial-melting processes, only minor amounts of water are available due to 
previously-altered protoliths. In our model most of the water released due to the breakdown of alteration phases migrates up at the prevailing supercritical conditions because it is an 'open cooking pot' rather than a closed system with a lid. Thus, an $a \mathrm{H}_{2} \mathrm{O}$ below 0.5 can be reached.

\section{The absence of amphibole-rich rocks as possible protoliths for felsic melt generation}

Amphibole-rich protoliths are often used to explain the generation of felsic melts at midocean ridges (e.g., Haase et al. 2005; Brophy 2008; Rollinson 2009; Wanless et al. 2010). However, one surprising aspect of this study is that amphibole was never produced as a residual phase in our experiments, although most experiments were performed under watersaturated conditions. The reason for the absence of amphibole is probably the very low pressure at which the experiments were performed, since it is well-known that too-low pressure destabilizes amphibole (e.g., Rutherford and Devine 2003). The absence of amphibole is in agreement with the natural drilling record from IODP Site 1256, where amphibole exists in those two-pyroxene hornfelses from the lowermost horizon of the sheeted dikes only as a secondary phase generated by a stage of hydrothermal overprint after the peak metamorphism (e.g. Zhang et al. 2014; Koepke and Goetze, in press). Amphibole as part of the prograde metamorphic paragenesis occurs only at a higher crustal level where the heat supply of the underlying AML is minor, away from the zone where the main anatectic processes are ongoing. Koepke et al. (2008) and Alt et al. (2010) present equilibration temperatures varying from $650^{\circ} \mathrm{C}$ to $854^{\circ} \mathrm{C}$ and from $464^{\circ} \mathrm{C}$ to $913^{\circ} \mathrm{C}$, respectively, for amphiboles in hornfelses, and similar amphibole-bearing hornfelses with equilibrium temperatures between 850 and $900^{\circ} \mathrm{C}$ were reported from Pito Deep (EPR) and the Troodos ophiolite (Gillis 2008). These temperatures are in the range of the solidus of altered basalts (France et al. 2010; this study). Thus, such rocks may be regarded as residues remaining after a partial melting process, provided the $a \mathrm{H}_{2} \mathrm{O}$ was very high; this possibility can be excluded for the anatectic conditions at Site 1256. It seems that the critical point is whether water 
liberated during the partial melting reaction can escape the zone of reaction or not; such escape is, in turn, is depending on the velocity of the uprising heat source (heat emanating from the AML after replenishment), and the efficiency of establishing a fluid pathway system in the caprocks overlying the reaction zone.

\section{CONCLUSION}

We experimentally simulated anatectic processes occurring at the roof of an oceanic magma chamber at fast-spreading ridges with special focus on IODP drilling Site 1256, representing $15 \mathrm{Ma}$ old crust generated at the EPR. To accomplish this, we partially melted different lithologies drilled at Hole 1256D and compared the experimental results (melts and residues) with the natural counterparts from the same location (felsic rocks and 2-pyroxene hornfels). Our results lead to the following conclusions:

(I) The experimental melt composition is strongly influenced by the degree of alteration/recrystallization of the starting material. The first melts in the comparative experimental studies of Beard and Lofgren (1991) and France et al. (2010) using strongly-altered starting material show, for example, strong enrichments in $\mathrm{K}_{2} \mathrm{O}$ caused by pervasive hydrothermal circulation in the protolith. Those high values $\left(\mathrm{K}_{2} \mathrm{O}>>0.3 \mathrm{wt} \%\right)$ are in contrast to natural tonalites from Hole 1256D. Except for the strongly-altered starting material GD12, all other starting materials lead to low $\mathrm{K}_{2} \mathrm{O}$ concentration in the partial melts, following the trend to direct $\mathrm{SiO}_{2}$ enrichment which reproduces the natural trend.

(II) The expected residue (i.e. 2-pyroxene hornfels) is reproduced in the residual experimental mineral composition (modal and chemical) at low melting degrees $(<20$ vol\%). 
(III) Equilibrium temperatures of granoblastic hornfels, estimated by several studies (e.g. Koepke et al. 2008; Koepke und Goetze, in press), imply high temperatures of $930^{\circ} \mathrm{C}$ to $1045^{\circ} \mathrm{C}$ for anatectic processes, leading to high $\mathrm{F}$ under water-saturated conditions ( $\mathrm{F}$ up to 50 vol\%), resulting in $\mathrm{SiO}_{2}$ contents which are, in general, too low in comparison to the natural counterparts. Moreover, the use of granoblastic two-pyroxene hornfels as starting material leads to low $\mathrm{F}$ (e.g., $\mathrm{F} \sim 10$ vol\% at $\mathrm{T}=970^{\circ} \mathrm{C}$ ). However, the corresponding melts are too low in $\mathrm{SiO}_{2}$ when compared with the natural tonalites, implying that these rocks are unlikely to be protoliths (Fig. 9).

(IV) At low $\mathrm{F}$ and high $\mathrm{SiO}_{2}(>70 \mathrm{wt} \%)$, the low $\mathrm{P}_{2} \mathrm{O}_{5}$ values of $1256 \mathrm{D}$ tonalites are experimentally reproduced. This implies that apatite is stable at these conditions. The relatively large amounts of rare earth elements, Y, and $\mathrm{Sr}$ found in apatite are held back from the melt, due to the high distribution coefficients apatite has for these elements. This can explain the expected relatively low enrichment of anatectic melt in these trace elements (e.g., Brophy 2009) compared to evolved melts generated by fractional crystallization.

(V) Because experimental melts are generally higher in $\mathrm{Al}_{2} \mathrm{O}_{3}$ than are $1256 \mathrm{D}$ tonalites, the assumption of partial melting under water saturation has to be scrutinized. Experiments performed at water-undersaturated conditions exhibit a good correlation to natural counterparts with the best fit at $a \mathrm{H}_{2} \mathrm{O}=0.1$. Moreover, only at reduced $a \mathrm{H}_{2} \mathrm{O}$ can a low melting degree and thus high $\mathrm{SiO}_{2}$ content in anatectic melts be realized in the temperature range obtained for the peak metamorphic event $\left(930^{\circ} \mathrm{C}\right.$ to $\left.1045^{\circ} \mathrm{C}\right)$, when using the most likely protolith (i.e. moderately-altered basaltic dike). Low $a \mathrm{H}_{2} \mathrm{O}$ is also indicated by 
the An content of plagioclase in the natural hornfels, which is best mirrored in the experimental residues at reduced $a \mathrm{H}_{2} \mathrm{O}$.

(VI) The lack of amphibole in our experimental residue supports the observations in two-pyroxene hornfels from IODP Site 1256 where amphibole only occurs as a secondary phase, generated by a late stage hydrothermal overprint (e.g. Zhang et al. 2014; Koepke and Goetze, in press). Thus, amphibole-rich protoliths for anatexis at the dike/gabbro transition from present day fast-spreading ridges, which are often used for chemical modeling of felsic rock suites in the oceanic crust, are probably less important.

\section{ACKNOWLEDGMENTS}

We thank Otto Dietrich and Julian Feige for their careful sample preparation. The manuscript has been substantially improved after thorough reviews by M. Perfit and two anonymous reviewers. This research used samples and/or data provided by the International Ocean Drilling Program (IODP). IODP is sponsored by the U.S. National Science Foundation (NSF) and participating countries under management of the Consortium for Ocean Leadership (COL). Funding for this research was provided by grants from the Deutsche Forschungsgemeinschaft (KO 1723/13). 


\section{REFERENCES}

Alt JC, Laverne C, Coggon RM, Teagle DAH, Banerjee NR, Morgan S, Smith-Duque CE, Harris M, Galli L (2010) Subsurface structure of a submarine hydrothermal system in ocean crust formed at the East Pacific Rise, ODP/IODP Site 1256. Geochemistry, Geophysics, Geosystems 11(10):Q10010. doi: 10.1029/2010gc003144

Andersen DJ, Lindsley DH, Davidson PM (1993) QUILF: A pascal program to assess equilibria among Fe-MgMn-Ti oxides, pyroxenes, olivine, and quartz. Computers \& Geosciences 19(9):1333-1350

Barker F (1979) Trondhjemites, dacites and related rocks. Elsevier, Amsterdam:659 pp

Beard JS (1990) Partial melting of metabasites in the contact aureoles of gabbroic plutons in the Smartville complex, Sierra Nevada, California. The nature and origin of Cordilleran magmatism. Geol. Soc. Am. Mem. $174: 303-313$

Beard JS, Lofgren GE (1991) Dehydration Melting and Water-Saturated Melting of Basaltic and Andesitic Greenstones and Amphibolites at 1, 3, and 6. 9 kb. Journal of Petrology 32(2):365-401. doi: 10.1093/petrology/32.2.365

Berndt J, Koepke J, Holtz FO (2005) An Experimental Investigation of the Influence of Water and Oxygen Fugacity on Differentiation of MORB at 200MPa. Journal of Petrology 46(1):135-167. doi: 10.1093/petrology/egh066

Berndt J, Liebske C, Holtz F, Freise M, Nowak M, Ziegenbein D, Hurkuck W, Koepke J (2002) A combined rapid-quench and H2-membrane setup for internally heated pressure vessels: Description and application for water solubility in basaltic melts. American Mineralogist 87(11-12):1717-1726

Bézos A, Humler E (2005) The Fe3+/[Sigma]Fe ratios of MORB glasses and their implications for mantle melting. Geochimica et Cosmochimica Acta 69(3):711-725

Blackman DK, Ildefonse B, John BE, MacLeod CJ, Ohara Y, Miller DJ, Team tEP (2004) Oceanic core complex formation, Atlantis Massif-oceanic core complex formation, Atlantis Massif, Mid-Atlantic Ridge: drilling into the footwall and hanging wall of a tectonic exposure of deep, young oceanic lithosphere to study deformation, alteration, and melt generation. IODP Sci. Prosp. 304/305. doi:10.2204/iodp.sp.304305.2004

Brey GP, Koehler T (1990) Geothermobarometry in Four-phase Lherzolites II. New Thermobarometers, and Practical Assessment of Existing Thermobarometers. Journal of Petrology 31(6):1353-1378. doi: 10.1093/petrology/31.6.1353

Brophy J (2008) A study of rare earth element (REE)SiO2 variations in felsic liquids generated by basalt fractionation and amphibolite melting: a potential test for discriminating between the two different processes. Contributions to Mineralogy and Petrology 156:337-357

Brophy $\mathrm{J}$ (2009) $\mathrm{La}-\mathrm{SiO}[2]$ and $\mathrm{Yb}-\mathrm{SiO}[2]$ systematics in mid-ocean ridge magmas: implications for the origin of oceanic plagiogranite. Contributions to Mineralogy and Petrology 158(1):99-111. doi: 10.1007/s00410-0080372-3

Burnham C (1981) The nature of multicomponent aluminosilicate melts. Physics and Chemistry of The Earth 13$14: 197-229$

Byerly GR, Melson WG, Vogt PR (1976) Rhyodacites, andesites, ferro-basalts and ocean tholeiites from the galapagos spreading center. Earth and Planetary Science Letters 30(2):215-221

Caress DW, Burnett MS, Orcutt JA (1992) Tomographic image of the axial low-velocity zone at $12^{\circ} 50^{\prime} \mathrm{N}$ on the East Pacific Rise. Journal of Geophysical Research: Solid Earth 97(B6):9243-9263. doi: 10.1029/92jb00287

Coleman RG, Peterman ZE (1975) Oceanic Plagiogranite. J. Geophys. Res. 80(8):1099-1108. doi: 10.1029/JB080i008p01099

Coogan LA, Mitchell NC, O'Hara MJ (2003) Roof assimilation at fast spreading ridges: An investigation combining geophysical, geochemical, and field evidence. J. Geophys. Res. 108(B1):2002 
Cottrell E, Kelley KA (2011) The influence of magmatic differentiation on the oxidation state of Fe in a basaltic arc magma. Earth and Planetary Science Letters 305(3-4):270-282

Crawford WC, Webb SC, Hildebrand JA (1999) Constraints on melt in the lower crust and Moho at the East Pacific Rise, $9^{\circ} 48^{\prime} \mathrm{N}$, using seafloor compliance measurements. Journal of Geophysical Research: Solid Earth 104(B2):2923-2939. doi: 10.1029/1998jb900087

Detrick RS, Buhl P, Vera E, Mutter J, Orcutt J, Madsen J, Brocher T (1987) Multi-channel seismic imaging of a crustal magma chamber along the East Pacific Rise. Nature 326(6108):35-41

Devine JD, Gardner JE, Brack HP, Layne GD, Rutherford MJ (1995) Comparison of microanalytical methods for estimating H 2 O contents of silicic volcanic glasses. American Mineralogist 80(3-4):319-328

Dick HJB, Natland JH, Alt JC, et al. (2000) A long in situ section of the lower ocean crust: results of ODP Leg 176 drilling at the Southwest Indian Ridge. Earth and Planetary Science Letters 179(1):31-51

Dunn RA, Toomey DR, Solomon SC (2000) Three-dimensional seismic structure and physical properties of the crust and shallow mantle beneath the East Pacific Rise at $9^{\circ} 30^{\prime}$ N. Journal of Geophysical Research: Solid Earth 105(B10):23537-23555. doi: 10.1029/2000jb900210

Ernst WG, Liu JUN (1998) Experimental phase-equilibrium study of Al and Ti-contents of calcic amphibole in MORB - A semiquantitative thermobarometer, vol 83. Am. Mineral.,

Feig S, Koepke J, Snow J (2006) Effect of water on tholeiitic basalt phase equilibria: an experimental study under oxidizing conditions. Contributions to Mineralogy and Petrology 152(5):611-638. doi: 10.1007/s00410006-0123-2

France L, Ildefonse B, Koepke J (2009) Interactions between magma and hydrothermal system in Oman ophiolite and in IODP Hole 1256D: Fossilization of a dynamic melt lens at fast spreading ridges. Geochem. Geophys. Geosyst. 10(10):Q10O19. doi: 10.1029/2009gc002652

France L, Ildefonse B, Koepke J (2013) Hydrous magmatism triggered by assimilation of hydrothermally altered rocks in fossil oceanic crust (northern Oman ophiolite). Geochemistry, Geophysics, Geosystems 14(8):25982614. doi: $10.1002 /$ ggge.20137

France L, Koepke J, Ildefonse B, Cichy S, Deschamps F (2010) Hydrous partial melting in the sheeted dike complex at fast spreading ridges: experimental and natural observations. Contributions to Mineralogy and Petrology 160(5):683-704. doi: 10.1007/s00410-010-0502-6

France L, Koepke J, MacLeod CJ, Ildefonse B, Godard M, Deloule E (2014) Contamination of MORB by anatexis of magma chamber roof rocks: Constraints from a geochemical study of experimental melts and associated residues. Lithos 202-203(0):120-137. doi: 10.1016/j.lithos.2014.05.018

Freund S (2014) The generation of felsic magmas in the oceanic crust: assimilation-fractional crystallization processes versus re-melting of the crust. Dissertation, Friedrich-Alexander-Universitaet Erlangen-Nuernberg

Freund S, Beier C, Krumm S, Haase KM (2013) Oxygen isotope evidence for the formation of andesitic-dacitic magmas from the fast-spreading Pacific-Antarctic Rise by assimilation-fractional crystallisation. Chemical Geology 347(0):271-283. doi: 10.1016/j.chemgeo.2013.04.013

Gaetani GA, Grove TL, Bryan WB (1993) The influence of water on the petrogenesis of subductionrelated igneous rocks. Nature 365(6444):332-334

Gale A, Dalton CA, Langmuir CH, Su Y, Schilling J-G (2013) The mean composition of ocean ridge basalts. Geochemistry, Geophysics, Geosystems 14(3):489-518. doi: 10.1029/2012gc004334

Gillis KM (2008) The roof of an axial magma chamber: A hornfelsic heat exchanger. Geology 36(4):299-302. doi: $10.1130 / \mathrm{g} 24590 \mathrm{a} .1$

Gillis KM, Coogan LA (2002) Anatectic Migmatites from the Roof of an Ocean Ridge Magma Chamber. Journal of Petrology 43(11):2075-2095. doi: 10.1093/petrology/43.11.2075

Gillis KM, Roberts MD (1999) Cracking at the magma-hydrothermal transition: evidence from the Troodos Ophiolite, Cyprus. Earth and Planetary Science Letters 169:227-244. doi: 10.1016/S0012-821X(99)00087-4 
Grimes CB, Ushikubo T, Kozdon R, Valley JW (2013) Perspectives on the origin of plagiogranite in ophiolites from oxygen isotopes in zircon. Lithos 179(0):48-66. doi: 10.1016/j.lithos.2013.07.026

Haase KM, Freund S, Koepke J, Hauff V, Erdmann M (2015) Melts of sediments in the mantle wedge of the Oman ophiolite. Geology, First published online February 18, 2015. doi: 10.1130/G36451.1

Haase KM, Stroncik NA, Hekinian R, Stoffers P (2005) Nb-depleted andesites from the Pacific-Antarctic Rise as analogs for early continental crust. Geology 33(12):921-924. doi: 10.1130/g21899.1

Helz RT (1973) Phase Relations of Basalts in their Melting Range at PH2O = $5 \mathrm{~kb}$ as a Function of Oxygen Fugacity: Part I. Mafic Phases. Journal of Petrology 14(2):249-302. doi: 10.1093/petrology/14.2.249

Holland T, Blundy J (1994) Non-ideal interactions in calcic amphiboles and their bearing on amphiboleplagioclase thermometry. Contributions to Mineralogy and Petrology 116(4):433-447. doi: 10.1007/bf00310910

Holloway JR, Burnham C (1972) Melting relations of basalt with equilibrium water pressure less than total pressure. Journal of Petrology 13:1-29

Holtz F, Johannes W, Tamic N, Behrens H (2001) Maximum and minimum water contents of granitic melts generated in the crust: a reevaluation and implications. Lithos 56(1):1-14

Holtz F, Pichavant M, Barbey P, Johannes W (1992) Effects of H 2 O on liquidus phase relations in the haplogranite system at 2 and 5 kbar. American Mineralogist 77(11-12):1223-1241

Johannes W, Holtz F (1996) Petrogenesis and Experimetal Petrology of Granitic Rocks. Springer Verlag, Heidelberg

Johannes W, Koepke J (2001) Incomplete reaction of plagioclase in experimental dehydration melting of amphibolite. Australian Journal of Earth Sciences: An International Geoscience Journal of the Geological Society of Australia 48(4):581 - 590

Kawamoto T (1996) Experimental constraints on differentiation and $\mathrm{H} 2 \mathrm{O}$ abundance of calc-alkaline magmas. Earth and Planetary Science Letters 144(3â€“4):577-589. doi: 10.1016/S0012-821X(96)00182-3

Koepke J, Berndt J, Bussy F (2003) An experimental study on the shallow-level migmatization of ferrogabbros from the Fuerteventura Basal Complex, Canary Islands. Lithos 69(3-4):105-125

Koepke J, Berndt J, Feig S, Holtz F (2007) The formation of SiO2-rich melts within the deep oceanic crust by hydrous partial melting of gabbros. Contributions to Mineralogy and Petrology 153(1):67-84. doi: 10.1007/s00410-006-0135-y

Koepke J, Berndt J, Horn I, Fahle J, Wolff PE (2014) Partial melting of oceanic gabbro triggered by migrating water-rich fluids: a prime example from the Oman Ophiolite. Geological Society, London, Special Publications 392(1):195-212. doi: 10.1144/sp392.10

Koepke J, Christie DM, Dziony W, Holtz F, Lattard D, Maclennan J, Park S, Scheibner B, Yamasaki T, Yamazaki S (2008) Petrography of the dike-gabbro transition at IODP Site 1256 (equatorial Pacific): The evolution of the granoblastic dikes. Geochem. Geophys. Geosyst. 9(7):Q07O09. doi: 10.1029/2008gc001939

Koepke J, Feig S, Snow J (2005a) Late stage magmatic evolution of oceanic gabbros as a result of hydrous partial melting: Evidence from the Ocean Drilling Program (ODP) Leg 153 drilling at the Mid-Atlantic Ridge. Geochem. Geophys. Geosyst. 6(2):Q02001. doi: 10.1029/2004gc000805

Koepke J, Feig ST, Snow J (2005b) Hydrous partial melting within the lower oceanic crust. Terra Nova 17(3):286-291. doi: 10.1111/j.1365-3121.2005.00613.x

Koepke J, Feig S, Snow J, Freise M (2004) Petrogenesis of oceanic plagiogranites by partial melting of gabbros: an experimental study. Contributions to Mineralogy and Petrology 146(4):414-432. doi: 10.1007/s00410-0030511-9

Koepke J, France L, Müller T, Faure F, Goetze N, Dziony W, Ildefonse B (2011) Gabbros from IODP Site 1256, equatorial Pacific: Insight into axial magma chamber processes at fast spreading ocean ridges. Geochem. Geophys. Geosyst. 12(9):Q09014. doi: 10.1029/2011gc003655 
Koepke J, Goetze N (in press) Data report: Microanalytical and geothermometric investigations on granoblastic dikes from the gabbro/dike transition from Hole 1256D (IODP Expedition 335, East Pacific Rise). Proc ODP Sci

Koepke J, Schoenborn S, Oelze M, Wittmann H, Feig ST, Hellebrand E, Boudier F, Schoenberg R (2009) Petrogenesis of crustal wehrlites in the Oman ophiolite: Experiments and natural rocks. Geochem. Geophys. Geosyst. 10(10):Q10002. doi: 10.1029/2009gc002488

Lamoureux Gl, Ildefonse BÌt, Mainprice D (1999) Modelling the seismic properties of fast-spreading ridge crustal Low-Velocity Zones: insights from Oman gabbro textures. Tectonophysics 312(2-4):283-301. doi: 10.1016/S0040-1951(99)00183-3

Lister CRB (1974) On the Penetration of Water into Hot Rock. Geophysical Journal International 39(3):465-509. doi: 10.1111/j.1365-246X.1974.tb05468.x

MacLeod CJ, Lissenberg CJ, Bibby LE (2013) "Moist MORB" axial magmatism in the Oman ophiolite: The evidence against a mid-ocean ridge origin. Geology. doi: 10.1130/g33904.1

McCaig AM, Harris M (2012) Hydrothermal circulation and the dike-gabbro transition in the detachment mode of slow seafloor spreading. Geology 40(4):367-370. doi: 10.1130/g32789.1

Michael P, Chase R (1987) The influence of primary magma composition, $\mathrm{H} 2 \mathrm{O}$ and pressure on mid-ocean ridge basalt differentiation. Contributions to Mineralogy and Petrology 96(2):245-263. doi: 10.1007/bf00375237

Michael PJ, Cornell WC (1998) Influence of spreading rate and magma supply on crystallization and assimilation beneath mid-ocean ridges: Evidence from chlorine and major element chemistry of mid-ocean ridge basalts. J. Geophys. Res. 103(B8):18325-18356. doi: 10.1029/98jb00791

Morgan VI GB, London D (2005) Effect of current density on the electron microprobe analysis of alkali aluminosilicate glasses American Mineralogist 90:1131-1138

Natland JH, Dick HJB (2009) Paired melt lenses at the East Pacific Rise and the pattern of melt flow through the gabbroic layer at a fast-spreading ridge. Lithos 112(1-2):73-86. doi: 10.1016/j.lithos.2009.06.017

Nicolas A, Boudier F (1991) Rooting of the Sheeted Dike Complex in the Oman Ophiolite. In: Peters T, Nicolas A, Coleman RG (eds) Ophiolite Genesis and Evolution of the Oceanic Lithosphere, vol 5. Springer Netherlands, pp 39-54. doi: 10.1007/978-94-011-3358-6_4

Nicolas A, Boudier F, Ildefonse B, Ball E (2000) Accretion of Oman and United Arab Emirates ophiolite Discussion of a new structural map. Marine Geophysical Researches 21(3):147-180. doi: 10.1023/a:1026769727917

Nicolas A, Boudier F, Koepke J, France L, Ildefonse B, Mevel C (2008) Root zone of the sheeted dike complex in the Oman ophiolite. Geochem. Geophys. Geosyst. 9(5):Q05001. doi: 10.1029/2007gc001918

Nicolas A, Ceuleneer G, Boudier F, Misseri M (1988) Structural mapping in the Oman ophiolites: Mantle diapirism along an oceanic ridge. Tectonophysics 151(1-4):27-56. doi: 10.1016/0040-1951(88)90239-9

Parat F, Holtz F, Feig S (2008) Pre-eruptive Conditions of the Huerto Andesite (Fish Canyon System, San Juan Volcanic Field, Colorado): Influence of Volatiles (C-O-H-S) on Phase Equilibria and Mineral Composition. Journal of Petrology 49(5):911-935

Perfit MR, Fornari DJ, Malahoff A, Embley RW (1983) Geochemical Studies of Abyssal Lavas Recovered by DSRV Alvin From Eastern Galapagos Rift, Inca Transform, and Ecuador Rift 3. Trace Element Abundances and Petrogenesis. J. Geophys. Res. 88(B12):10551-10572

Perfit MR, Ridley WI, Jonasson IR (1999) Geologic, petrologic, and geochemical relationships between magmatism and massive sulfide mineralization along the Eastern Galapagos Spreading Center. Society of Economic Geologists Reviews of Economic Geology 10:75-100

Prowatke S, Klemme S (2006) Trace element partitioning between apatite and silicate melts. Geochimica et Cosmochimica Acta 70(17):4513-4527. doi: 10.1016/j.gca.2006.06.162

Purdy GM, Kong LSL, Christeson GL, Solomon SC (1992) Relationship between spreading rate and the seismic structure of mid-ocean ridges. Nature 355(6363):815-817 
Rollinson H (2009) New models for the genesis of plagiogranites in the Oman ophiolite. Lithos 112(3-4):603614

Rothery DA (1983) The base of a sheeted dyke complex, Oman ophiolite: implications for magma chambers at oceanic spreading axes. Journal of the Geological Society 140(2):287-296. doi: 10.1144/gsjgs.140.2.0287

Rutherford MJ, Devine JD (2003) Magmatic Conditions and Magma Ascent as Indicated by Hornblende Phase Equilibria and Reactions in the 1995-2002 Soufrière Hills Magma. Journal of Petrology 44(8):1433-1453

Scaillet B, Pichavant M, Roux J (1995) Experimental Crystallization of Leucogranite Magmas. Journal of Petrology 36(3):663-705. doi: 10.1093/petrology/36.3.663

Scaillet B, Pichavant M, Roux J, Humbert G, Lefevre A (1992) Improvements of the Shaw membrane technique for measurement and control of $\mathrm{f} \mathrm{H} 2$ at high temperatures and pressures. American Mineralogist 77(5-6):647655

Schneider CA, Rasband WS, Eliceiri KW (2012) NIH Image to ImageJ: 25 years of image analysis. Nat Meth 9(7):671-675

Teagle DAH, Alt JC, Umino S, Miyashita S, Banerjee NR, Wilson DS, and the Expedition 309/312 Scientists (2006) Proc. IODP, 309/312. Integrated Ocean Drilling Program Management International, Inc., Washington, DC

Teagle DAH, Ildefonse B, Blum P, and the Expedition 335 scientists (2012) Proceedings IODP, 335: Tokyo, Integrated Ocean Drilling Program Management International, Inc.

Umino S, Miyashita S, Hotta F, Adachi Y (2003) Along-strike variation of the sheeted dike complex in the Oman Ophiolite: Insights into subaxial ridge segment structures and the magma plumbing system. Geochemistry, Geophysics, Geosystems 4(9):8618. doi: 10.1029/2001gc000233

Wanless VD, Perfit MR, Ridley WI, Klein E (2010) Dacite Petrogenesis on Mid-Ocean Ridges: Evidence for Oceanic Crustal Melting and Assimilation. Journal of Petrology 51(12):2377-2410. doi: 10.1093/petrology/egq056

Wanless VD, Perfit MR, Ridley WI, Wallace PJ, Grimes CB, Klein EM (2011) Volatile abundances and oxygen isotopes in basaltic to dacitic lavas on mid-ocean ridges: The role of assimilation at spreading centers. Chemical Geology 287(1-2):54-65

Wilson DS (1996) Fastest known spreading on the Miocene Cocos-Pacific Plate Boundary. Geophysical Research Letters 23(21):3003-3006. doi: 10.1029/96g102893

Wilson DS, Teagle DAH, Alt JC, et al. (2006) Drilling to Gabbro in Intact Ocean Crust. Science 312(5776):1016-1020. doi: 10.1126/science.1126090

Wolf M, Wyllie P (1994) Dehydration-melting of amphibolite at 10 kbar: the effects of temperature and time. Contributions to Mineralogy and Petrology 115(4):369-383. doi: 10.1007/bf00320972

Wolff PE, Koepke J, Feig ST (2013) The reaction mechanism of fluid-induced partial melting of gabbro in the oceanic crust. European Journal of Mineralogy 25(3):279-298

Zhang C, Koepke J, Kirchner C, Goetze N, Behrens H (2014) Rapid hydrothermal cooling above the axial melt lens at fast-spreading mid-ocean ridge. Sci. Rep. 4 


\section{FIGURE CAPTIONS}

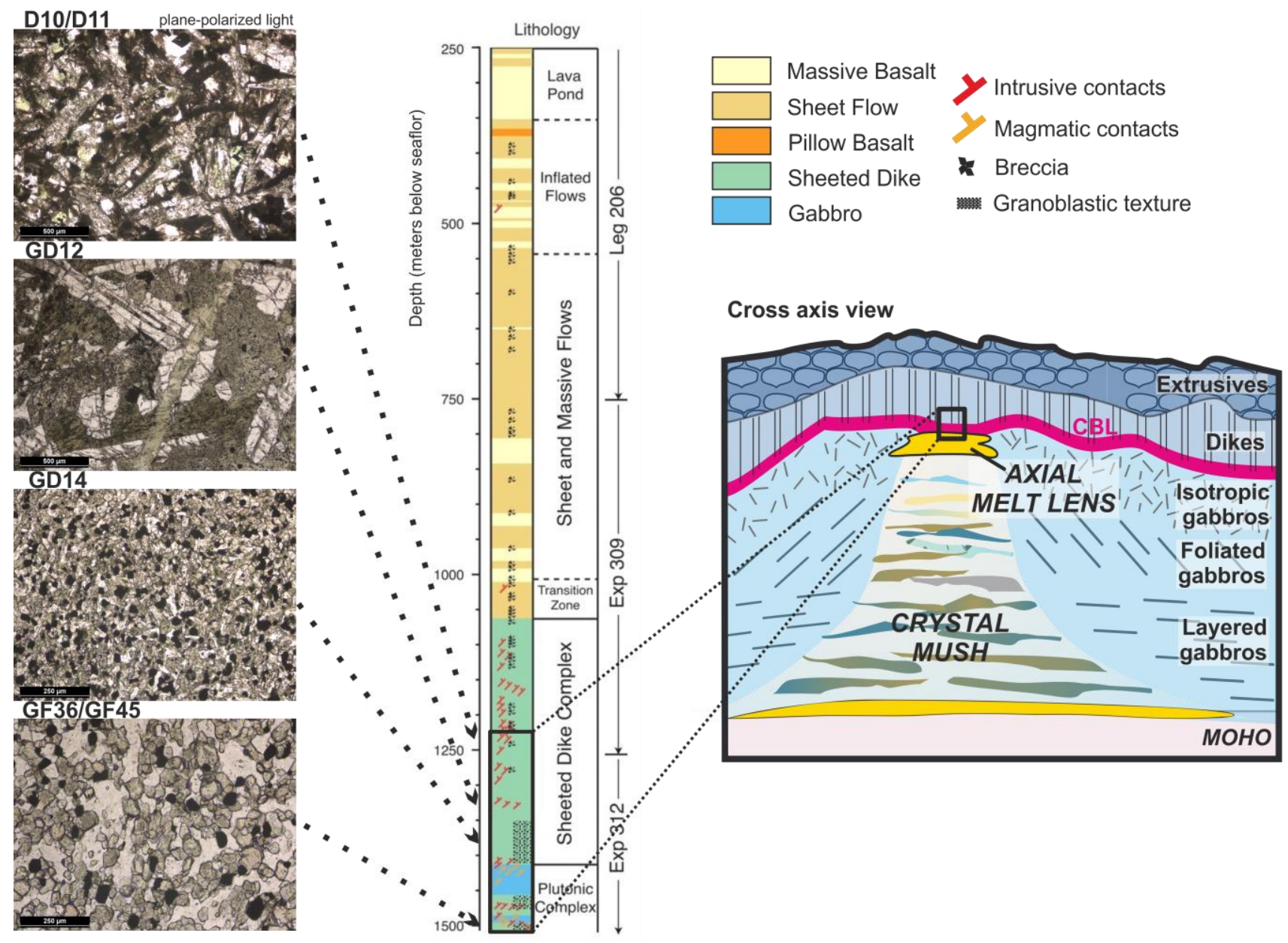

Fig. 1 Microphotographs of the different starting materials in plane-polarized light. D10 is very similar petrographically to D11 and GF36 to GF45; thus, only one example is shown for each pair. The depth at which each sample was taken is indicated on the IODP Site 1256 lithostratigraphic column (modified after Wilson et al. 2006). The sampled section of the column is shown by the small black rectangle in the schematic cross-axis view of the magmatic system at fast-spreading ridges (modified after France et al. 2014). This model (not to scale, vertical extent $\sim 6 \mathrm{~km}$ ) highlights the position of the AML (mainly composed of pure melt, yellow color) and the underlying crystal mush (less than $20 \%$ melt). At the base of this crystal mush another melt lens is illustrated (yellow) which corresponds to a model from Natland and Dick (2009). The conductive boundary layer (CBL) is highlighted in purple; it consists mainly of granoblastic hornfels 


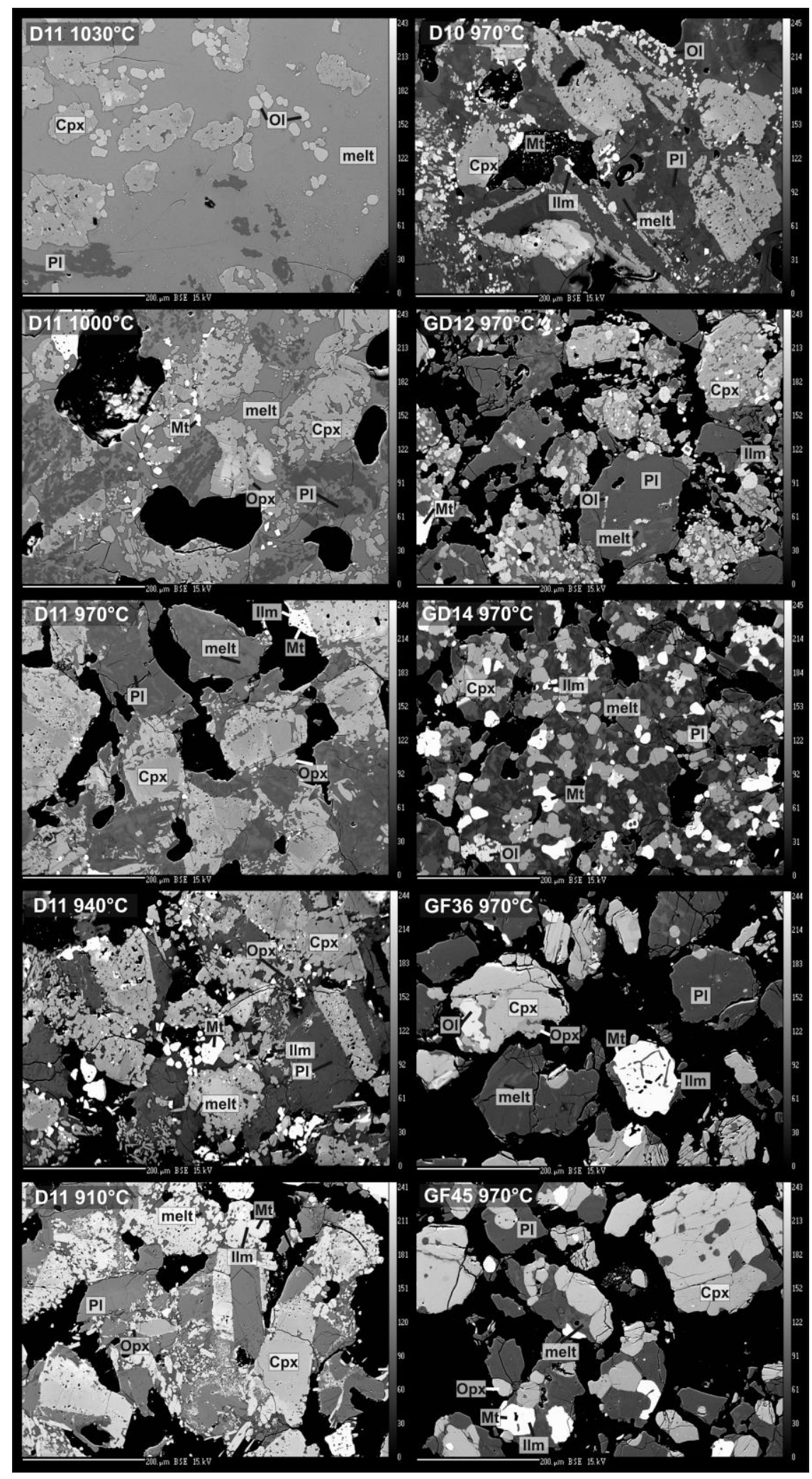

Fig. 2 Backscattered electron images of selected experimental results under water-saturated conditions. On the left, the complete temperature range (i.e. $910^{\circ} \mathrm{C}$ to $1030^{\circ} \mathrm{C}$ ) of starting material D11 is shown. On the right, all different starting materials are compared for $\mathrm{T}=970^{\circ} \mathrm{C}$. The scale $(200 \mu \mathrm{m})$ is the same for each image. Mineral abbreviations are the same as in Table 3 

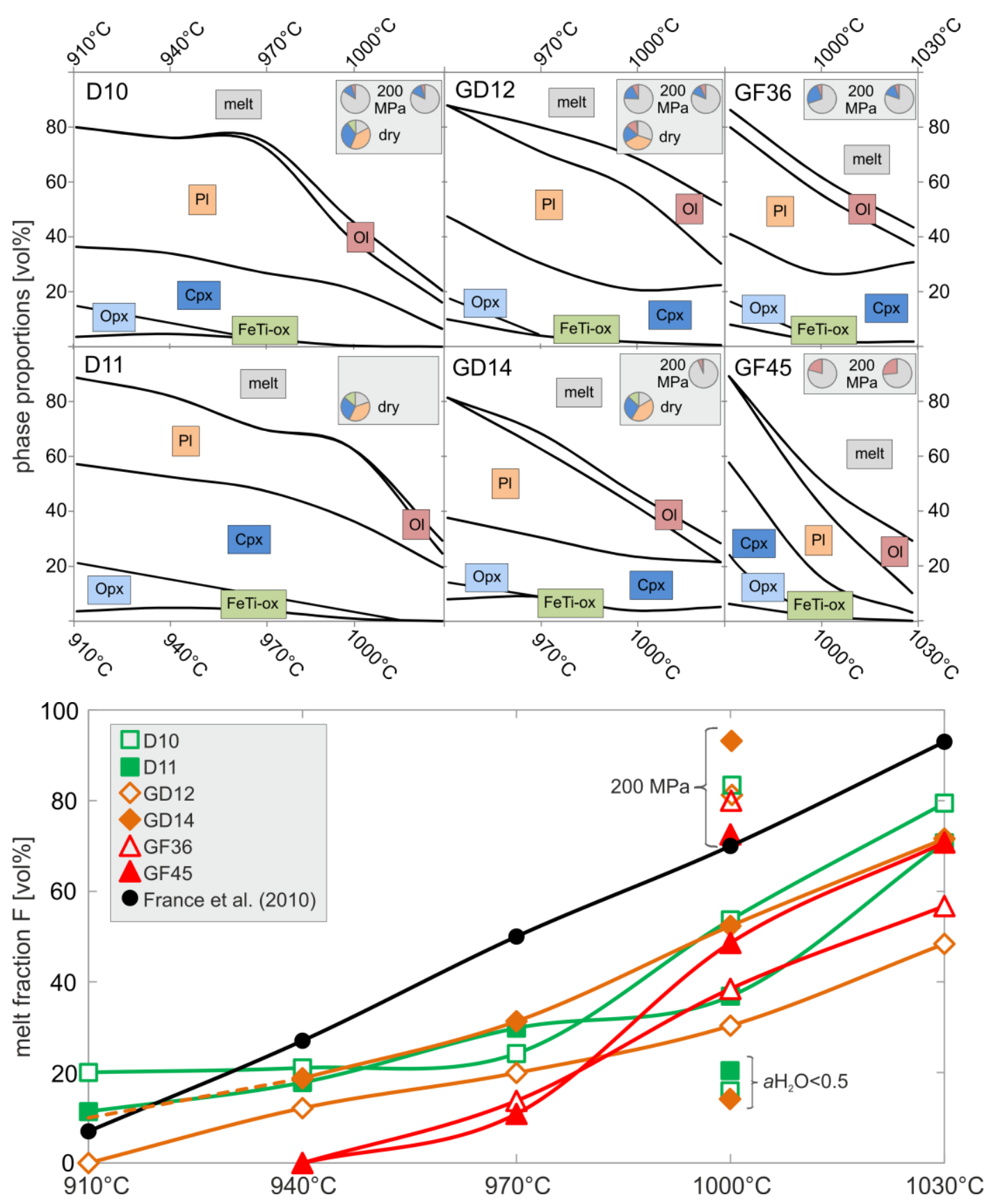

Fig. 3 a Phase proportions over the experimental temperature range for the different starting materials estimated by ImageJ (Schneider et al. 2012). Mineral abbreviations are the same as in Table 3; magnetite and ilmenite are summarized as FeTi-ox. In the box at the upper right of each graph the composition of experiments performed at $200 \mathrm{MPa}$ and low $a \mathrm{H}_{2} \mathrm{O}$, respectively, at the corresponding temperature are inserted as pie charts. Colors refer to the proportions of the corresponding phases indicated in the diagrams $\mathbf{b}$ Comparison of the melt fraction $(\mathrm{F})$ evolution with increasing temperature for the different starting materials. Experiments at $200 \mathrm{MPa}$ and low $a \mathrm{H}_{2} \mathrm{O}$, respectively, performed at $\mathrm{T}=1000^{\circ} \mathrm{C}$ are highlighted. Black data points refer to France et al.'s (2010) experiments. 


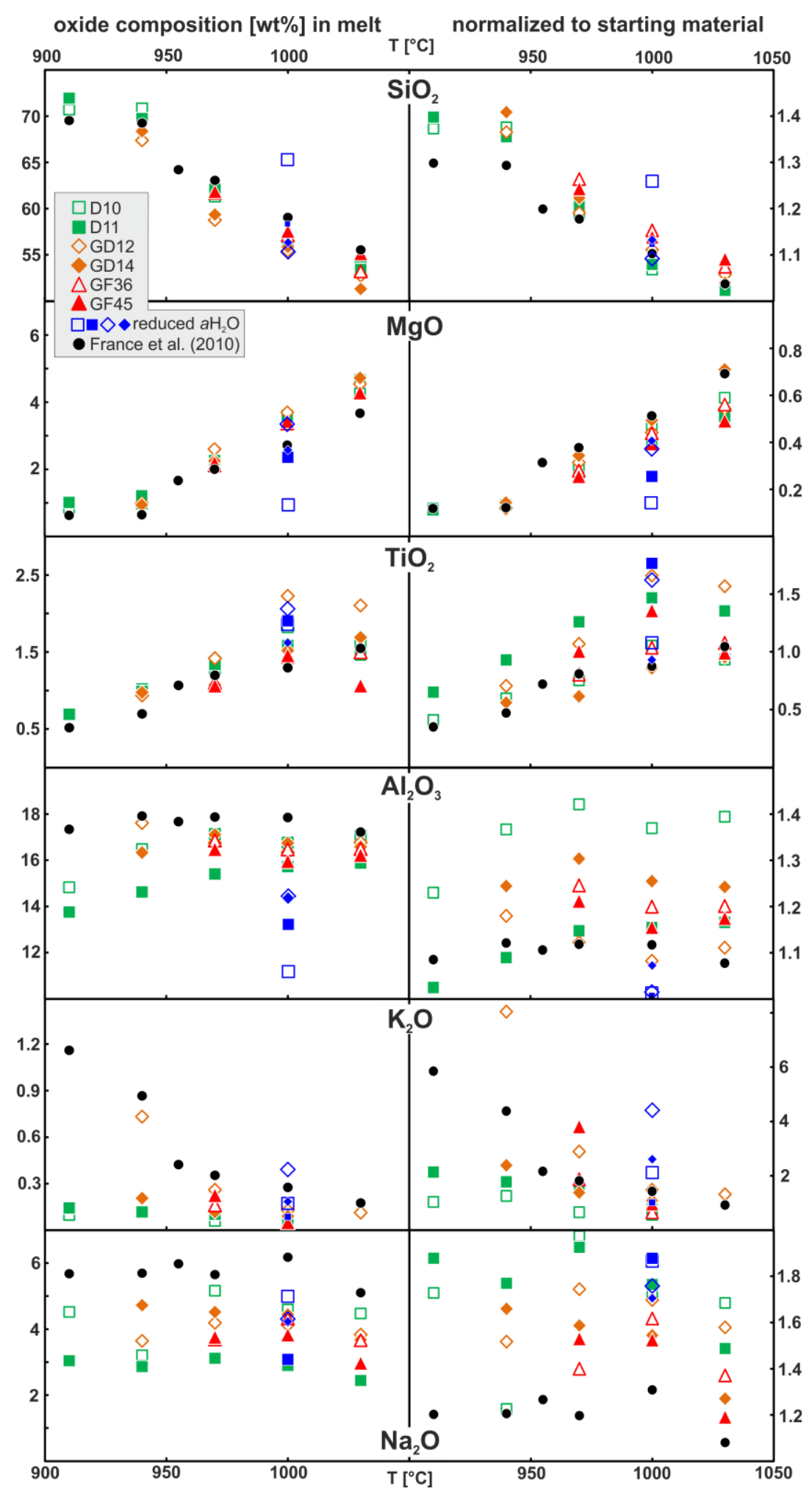

Fig. 4 Compositional evolution of experimental melts of different starting materials in wt $\%$ as a function of temperature (left column). The compositional evolution of the starting material was normalized in order to remove the influence of varying starting material composition (right column). Experiments performed at low $a \mathrm{H}_{2} \mathrm{O}$ are highlighted with blue data points. Black data points refer to France et al.'s (2010) experiments. 


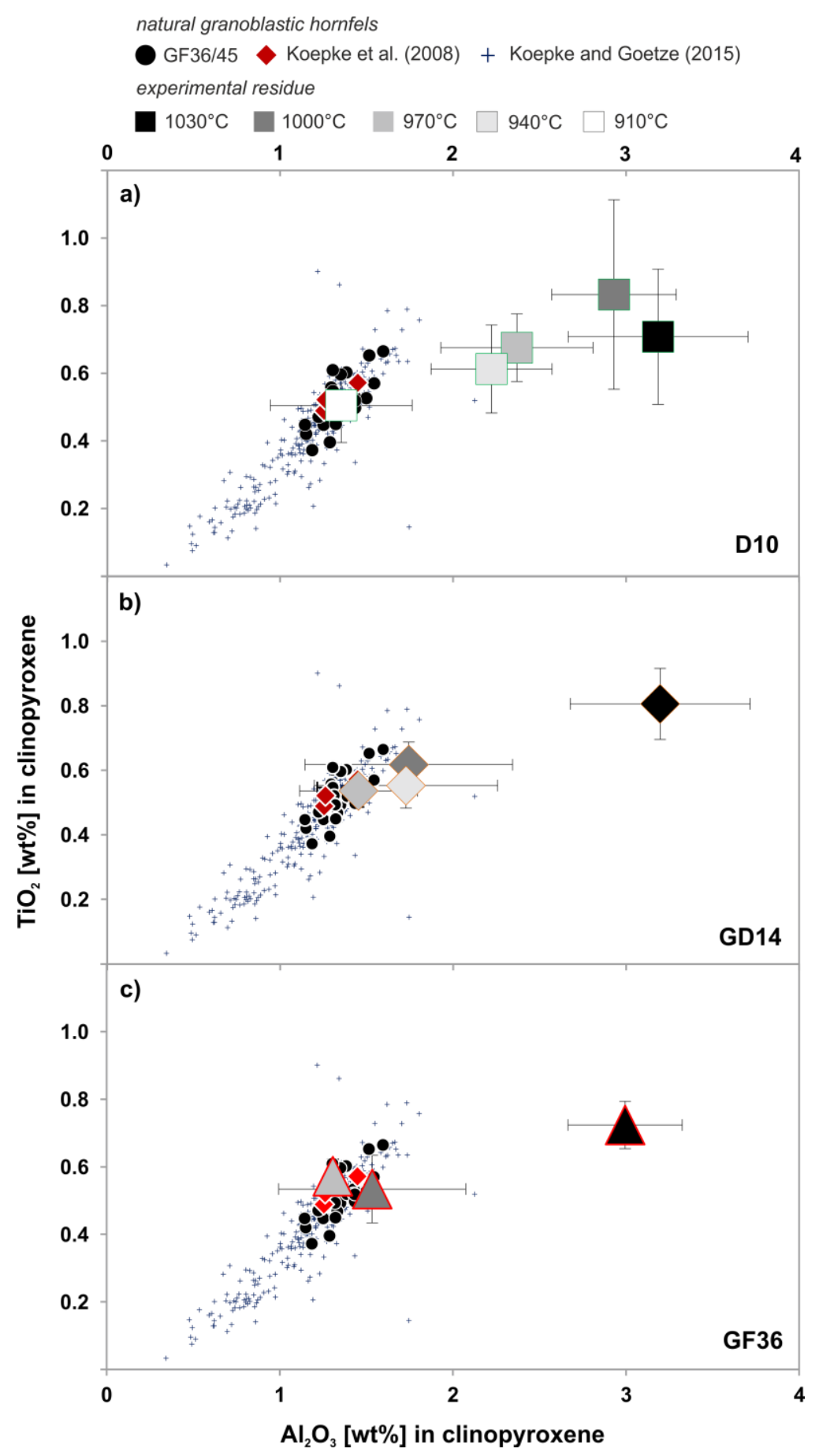

Fig. 5 Clinopyroxene compositions as a function of $\mathrm{TiO}_{2}$ and $\mathrm{Al}_{2} \mathrm{O}_{3}$. Shown are the average residual clinopyroxene compositions from experiments with starting materials D10 (a), GD14 (b), and GF36 (c) with a comparison to the clinopyroxene composition of natural "dry" (i.e. amphibole-free) granoblastic hornfels from IODP Site 1256. For this comparison, clinopyroxene compositions of "dry" granoblastic hornfels from this study (GF36 and GF45; black dots) are shown, as well as those measured by Koepke et al. (2008) and Koepke and Goetze (in press). The starting composition in $\mathbf{c}$ is shown by the black data points. Error bars represent the standard deviation of the single measurements. 


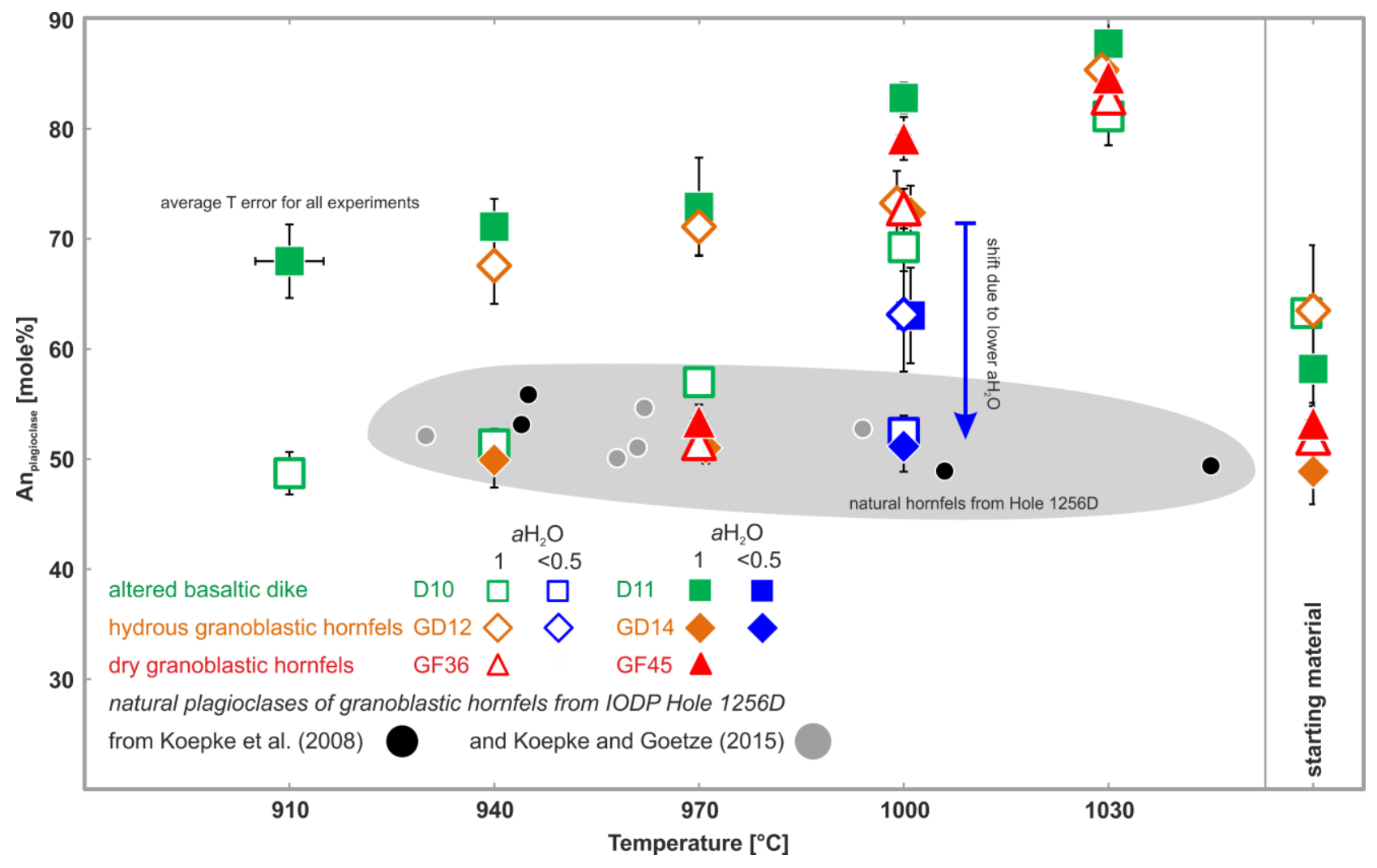

Fig. 6 An content of plagioclase as a function of temperature. Shown is the average plagioclase composition of the different starting materials and the average composition of newly-formed plagioclases from the experiments. Blue data points highlight experimental plagioclases formed under reduced $a \mathrm{H}_{2} \mathrm{O}\left(a \mathrm{H}_{2} \mathrm{O}=0.1\right.$ for D10, $a \mathrm{H}_{2} \mathrm{O} \sim 0.5$ for the others $)$. Note that the plagioclases of the starting material from D10, D11, and GD12 correspond to the primary magmatic plagioclase while those from GD14, GF36, and GF45 are of the metamorphic granoblastic assemblage. The grey field corresponds to natural plagioclases of granoblastic hornfels from IODP Site 1256. The temperatures were obtained by Koepke et al. (2008) and Koepke and Goetze (in press) by applying the two-pyroxene geothermometer in the corresponding natural rocks. 

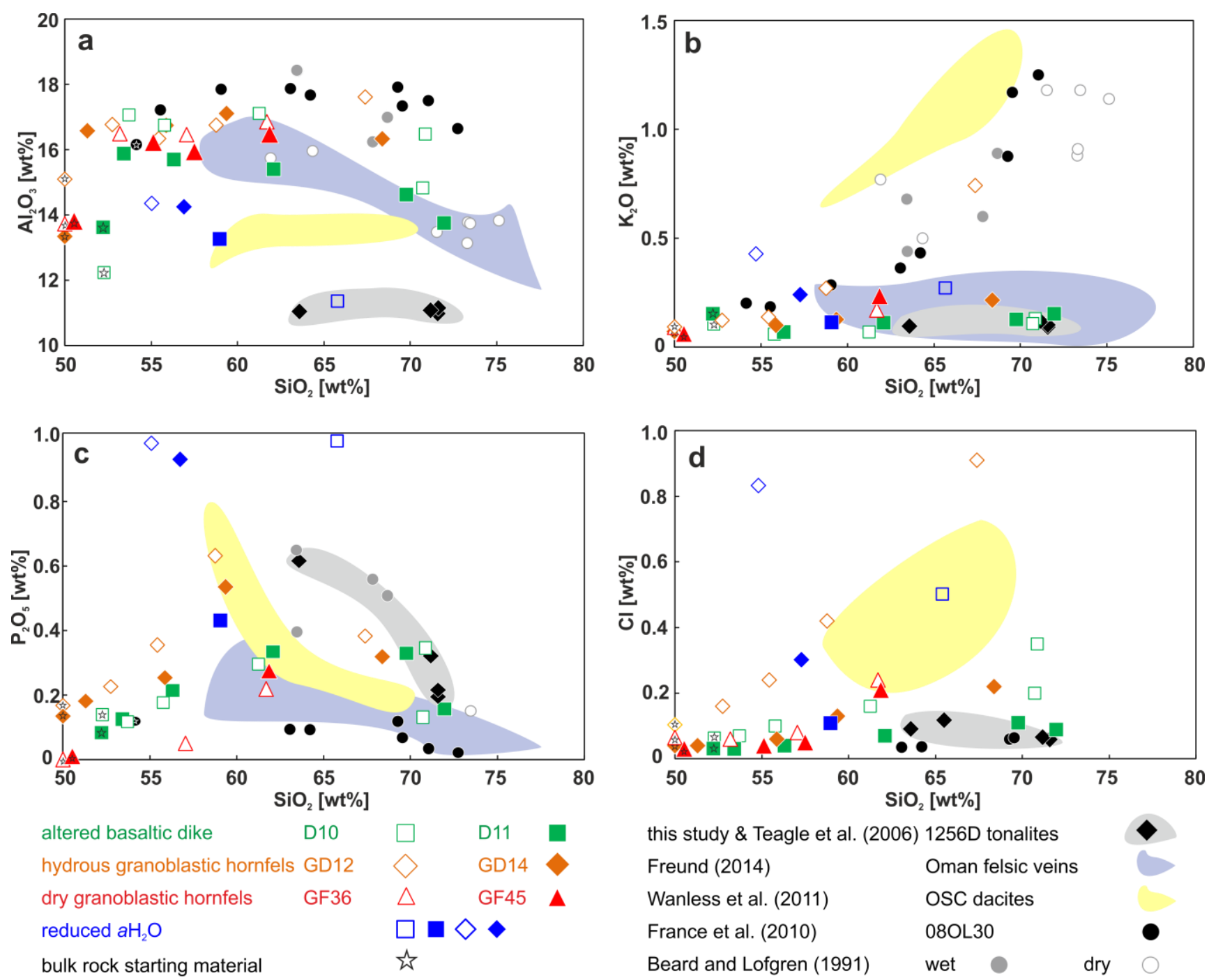

this study \& Teagle et al. (2006) 1256D tonalites Freund (2014)

Oman felsic veins

Wanless et al. (2011) OSC dacites

France et al. (2010) 08OL30

Beard and Lofgren (1991)

wet

dry

Fig. 7 Harker diagrams (oxide versus $\mathrm{SiO}_{2}$ ). Comparison of experimental melts from this study with experimental studies from Beard and Lofgren (1991) and France et al. (2010). Also shown are natural tonalite rock data from IODP Site 1256 (this study) and data from Oman ophiolite felsic veins (Freund 2014). Instead of Oman felsic veins for $\mathrm{Cl}$ (d), a comparison to dredged lavas from the $9^{\circ} \mathrm{N}$ overlapping spreading center (OSC) at the EPR is plotted (Wanless et al. 2011). The bulk rock composition of the starting materials is marked with stars, experiments performed at reduced $a \mathrm{H}_{2} \mathrm{O}$ are highlighted with blue data points. 


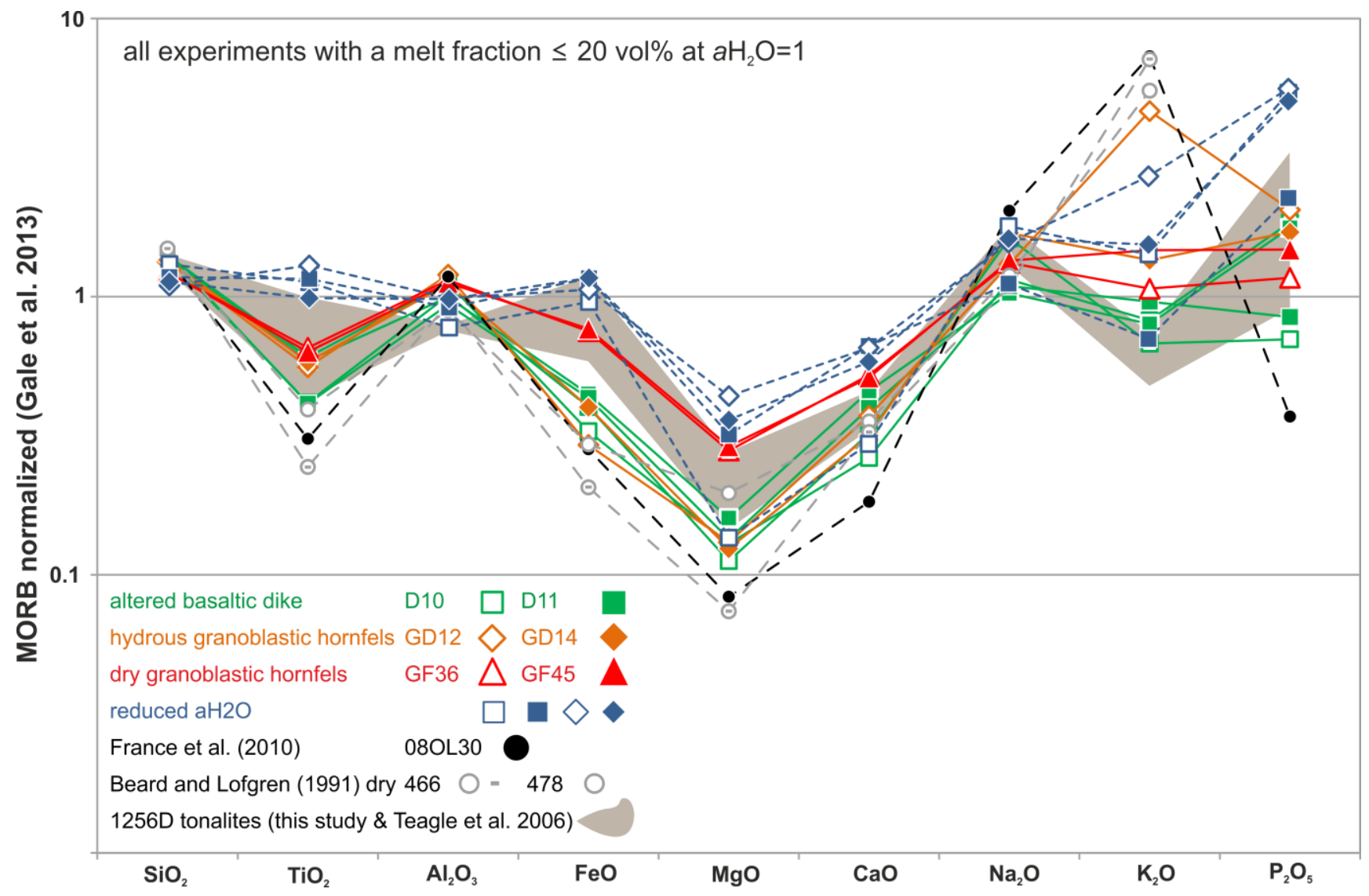

Fig. 8 Major element-MORB normalized diagram (using all MORB from Gale et al. 2013) for experimental melts and natural tonalites from IODP Site 1256 (grey field). Shown are all experiments from this study and from Beard and Lofgren (1991) and France et al. (2010) with a melt fraction $\leq 20 \mathrm{vol} \%$ in comparison to $1256 \mathrm{D}$ tonalites. Experiments performed at reduced $a \mathrm{H}_{2} \mathrm{O}$ are highlighted with blue data points. 

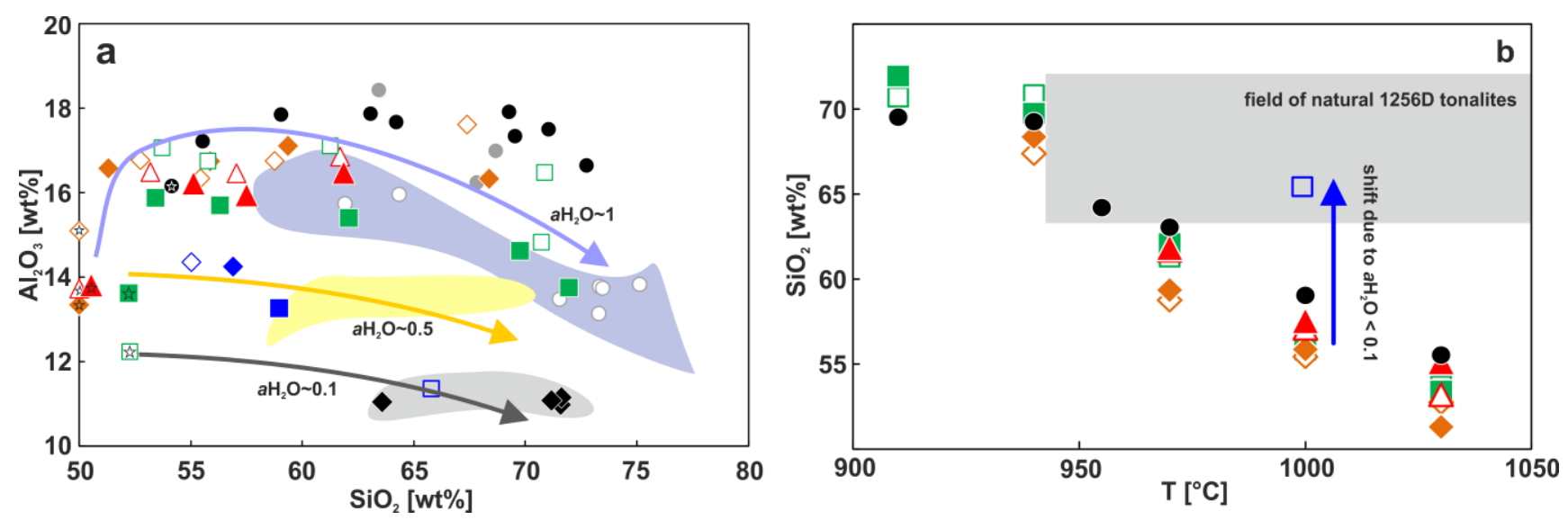

Fig. 9 a $\mathrm{Al}_{2} \mathrm{O}_{3}$ versus $\mathrm{SiO}_{2}$ as shown in Figure 7 a focusing on experiments performed at reduced $a \mathrm{H}_{2} \mathrm{O}$. Trends for the different $a \mathrm{H}_{2} \mathrm{Os}$ are highlighted with arrows. b $\mathrm{SiO}_{2}$ (wt\%) of the experimental melts as a function of temperature as shown in Figure 4a including the range of natural 1256D tonalite rock data obtained by this study and the temperature calculations of Koepke et al. (2008). The shift due to reduced $a \mathrm{H}_{2} \mathrm{O}$ is highlighted. 

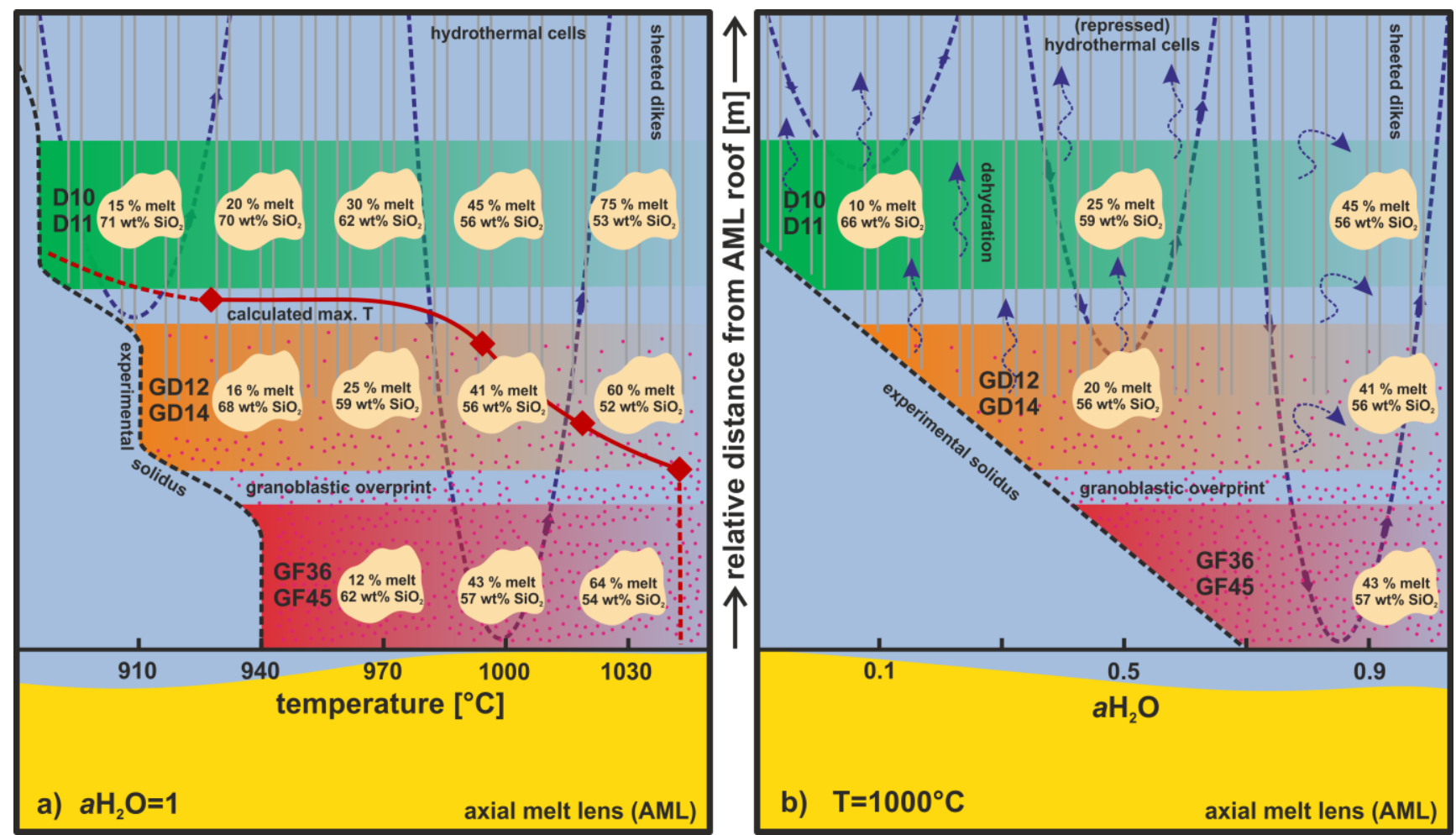

Fig. 10 Schematic model of the proposed stratigraphy at the oceanic magma chamber roof under a) water-saturated conditions and varying temperature or b) constant temperature $\left(1000^{\circ} \mathrm{C}\right)$ and different $a \mathrm{H}_{2} \mathrm{O}$. Shown are the generated felsic melts with melt volume (in vol\%) and $\mathrm{SiO}_{2}$ content for the different starting materials (with the average for each lithology) at the relative depth where they were sampled as a function of temperature (a) and $a \mathrm{H}_{2} \mathrm{O}$ (b). The granoblastic overprint is highlighted with purple dots. Blue dashed lines represent the hydrothermal cells (a and b) and potential dehydration at reduced $a \mathrm{H}_{2} \mathrm{O}$ (b only). The red curve in (a) is based on calculated 2-pyroxene maximum temperatures from Koepke et al. (2008) which are adapted for the depth from which the GD samples were taken. This curve highlights the result that that $\mathrm{D}$ samples can only be affected by anatexis when the AML and, thus, the temperature curve migrates upwards. 


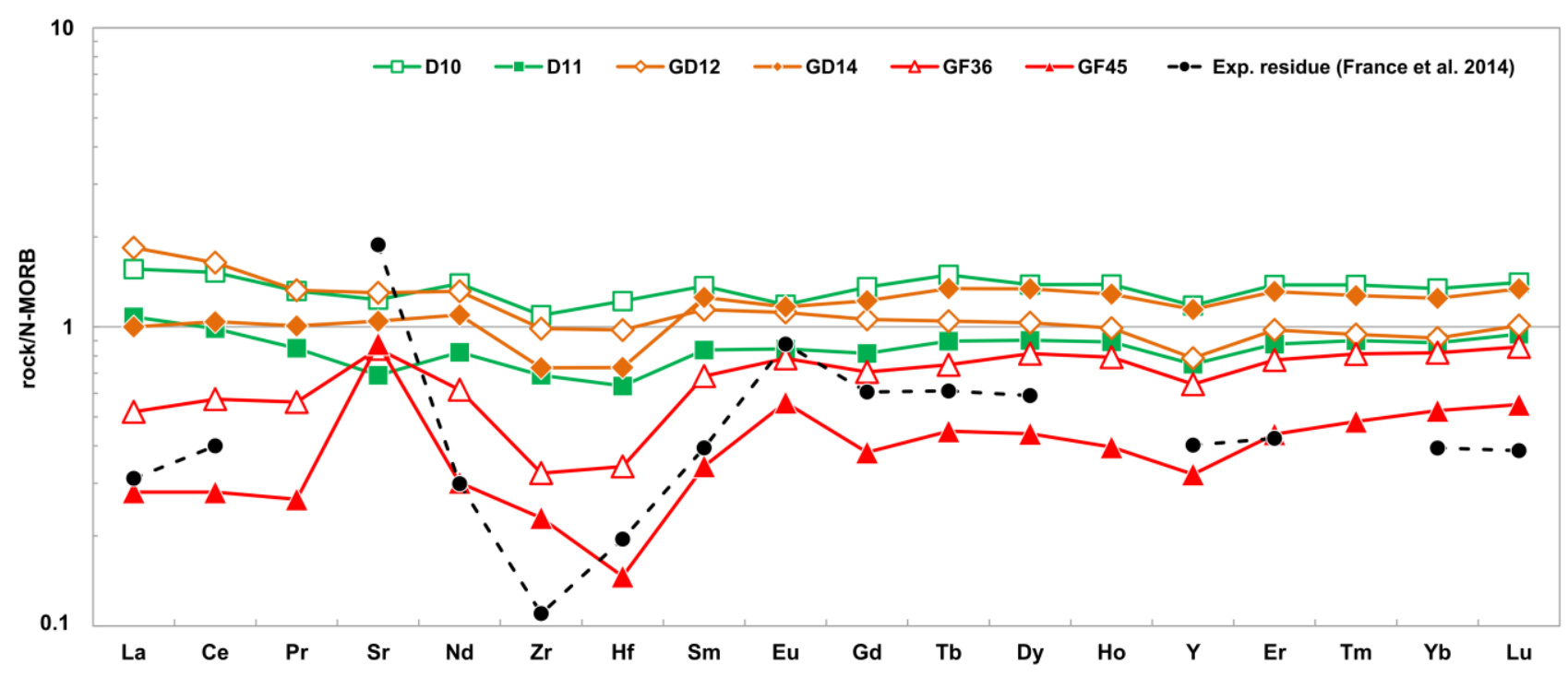

Fig. A1 electronic supplementary material N-MORB normalized (Gale et al. 2013) trace elements contents of the starting materials of this study and of natural tonalites from IODP Site 1256. Additionally shown is the calculated residual assemblage composition of the experiment with the lowest degree of partial melting (at $955^{\circ} \mathrm{C}$ ) published by France et al. (2014) 
Table 1 Comparison of the different starting compositions

Table 2 Experimental conditions

Table 3 Phase relations and reactions for the different starting materials

Table 4 Composition of the experimental melt obtained from the different starting materials

Table A1 electronic supplementary material Petrography and mineral modes of the different starting materials

Table A2 electronic supplementary material Composition of the experimental residue and the corresponding phases of the starting rock 
